\title{
Promoting Axon Regeneration and Neurological Recovery Following Traumatic Peripheral Nerve Injuries
}

\section{Damien P Kuffler*}

Institute of Neurobiology, Medical Sciences Campus, University of Puerto Rico, San Juan, PR 00901, USA

\begin{abstract}
Following a peripheral nerve crush, or when a peripheral the nerve is transected and the nerve stumps anastomosed, neurological recovery is generally excellent. This is because the axons merely have to regenerate through the distal portion of the nerve through the existing extracellular matrix of the denervated Schwann cells that direct and promote them to their distant denervated motor and sensory targets. However, when a length of a peripheral nerve is destroyed, and anastomosis is not possible, the standard surgical repair technique is to graft a length/s of autologous sensory nerve into the gap. Neurological recovery is generally good if the nerve gap is $<2 \mathrm{~cm}$ in length, the repair is performed $<4$ months post trauma, and the patients are $<25$ years of age. Because the nerve trauma parameters of large numbers of patients lie outside these limitations for the ability of nerve grafts to restore neurological function, many individuals suffer permanent neurological deficits. Although many alternative techniques have been tested for their ability to promote axon regeneration and neurological recovery, none is more effective than sensory nerve grafts and therefore, such grafts remain the clinical "gold standard" for nerve repairs. New techniques are required that induce more extensive axon regeneration and improved neurological recovery. This paper reviews the literature on many of the techniques tested for inducing axon regeneration across nerve gaps and inducing neurological recovery following traumatic peripheral nerve injuries, and discusses several novel techniques that clinically induce axon regeneration and neurological recovery under conditions where no other technique, including sensory nerve grafts, is effective.
\end{abstract}

Keywords: Nerve gaps; Nerve lesion; Neurological recovery; Axon regeneration

\section{Repairing Peripheral Nerves following Traumas}

\section{Nerve crush}

Within several days of crushing a peripheral nerve, the injured axons begin to regenerate through their distal pathway until they reach their original targets with which they restore neurological function. The larger the number of axons that regenerate through the distal nerve, the greater the extent of neurological recovery [1-3]. The number of axons that regenerate, and thus neurological recovery, is influenced by the physiological state of the distal denervated nerve pathway [4-7].

Following a peripheral nerve crush, the injured axons begin to regenerate within 2 days of injury [8]. They may regenerate to their targets through their original pathway in association with and promoted by its Schwann cells, the neurotrophic factors they release, and the Schwann cell extracellular matrix [1,4,9-14]. Thus, the distal nerve provides a simple means for promoting and directing the regenerating axons to their original targets [15-18]. However, when a nerve has a gap, the gap must be bridged with a material that is permissive to and promotes axon regeneration across the entire gap to reach the distal nerve stump, through which the axons must then be able to regenerate.

The Schwann cells in the denervated distal nerve release neurotrophic factors that promote axon regeneration, but also release extracellular matrix components that promote and inhibit axon regeneration [19-26]. Thus, regeneration through the distal nerve is a balance of the influences of factors that both promote and inhibit regeneration. If the Schwann cells are present, such as after a simple nerve crush, virtually $100 \%$ of the axons regenerate and they innervate all the denervated synaptic sites. If the Schwann cells within the distal nerve pathway are killed, leaving only the extracellular matrix intact, the number of axons that regenerates to their targets decreases by $94 \%$. This is because the factors required to trigger the regenerating axons to branch at extracellular matrix branch points are missing, axons do not branch, and therefore each axon reinnervates only a single denervated muscle fiber. Thus, Schwann cells along the distal nerve pathway and a diffusible the cocktail of Schwann cell-released factors are critical for promoting axon regeneration and branching and good reinnervation of distant denervated nerve targets [1-27].

The Schwann cell basal lamina of the extracellular matrix (ECM) promotes nerve regeneration following nerve transection by promoting Schwann cell colonization and promoting axonal guidance due to the presence of laminin within the ECM $[28,29]$. Thus, axon regeneration can be promoted by mimicing the native basal lamina by using basal lamina proteins from Matrigel (growth factor-reduced) extracted and electrospun to deposit nonwoven nanofiber mats. Such fabricated nanofiber mats support the attachment of cultured embryonic chick dorsal root ganglion explants, the elongation of neurites, and the migration of Schwann cells in a similar fashion compared to electrospun collagen type-I fibers repair. The extension of neurites and Schwann cell replication is significantly increased by the presence of nanorough surface features repair [29].

\section{Nerve transection - nerve gaps}

When a nerve is transected, the nerve stumps normally withdraw from one another by about $3 \mathrm{~mm}$. If the nerve stumps are immediately sutured together (anastomosed), neurological recovery is generally excellent [30]. The better the alignment of the nerve stumps to their original orientations $[31,32]$ and the shorter the distance between the ends of the nerve stumps [33-36] the better the accuracy of neurological recovery. However, even without aligning the nerve stumps, when a

*Corresponding author: Damien Kuffler, Institute of Neurobiology, 201 Blvd. Del Valle, San Juan, PR 00901, USA, Tel: 787-721-1235; E-mail: dkuffler@hotmail.com

Received November 13, 2014; Accepted January 12, 2015; Published January 18,2015

Citation: Kuffler DP (2015) Promoting Axon Regeneration and Neurological Recovery Following Traumatic Peripheral Nerve Injuries. Int J Neurorehabilitation 2: 148. doi:10.4172/2376-0281.1000148

Copyright: () 2015 Kuffler DP. This is an open-access article distributed under the terms of the Creative Commons Attribution License, which permits unrestricted use, distribution, and reproduction in any medium, provided the original author and source are credited. 
short gap $<3 \mathrm{~mm}$ in length is present between the nerve stumps, the axons find the distal nerve stump and innervate their original targets. This indicates that specific molecular cues indicate to sensory and motor axons their respective distal sensory and motor pathway [20,37]. Newer evidence indicates that in spite of long nerve gaps, up to 3-12 $\mathrm{cm}$ in length, regenerating axons can still precisely reinnervate their appropriate sensory and motor distal pathways [38,39]. Although the specificity of denervated sensory and motor nerves decreases over time, electrical stimulation of the denervated nerve restores the specificity of attraction of their appropriate sensory and motor axon types [40-42].

When a nerve pathway is damaged destroying a length of a nerve pathway (i.e. causing a nerve gap that is $<3 \mathrm{~mm}$ long), neurological recovery may occur without surgical intervention. This is due to a cascade of events by which fibrinogen seeps out of leaky blood vessels in the injury site where it combines with thrombin, causing fibrinogen polymerization and formation of a 3-dimensional fibrin matrix (scaffold) within the nerve gap [39,43-45]. Although a fibrin clot promotes axon regeneration, the influence of pure fibrin within a nerve gap is not extensive, but its influence is increased by the migration of Schwann cells into the fibrin from the cut central and distal nerve stumps. Once in the nerve gap, the Schwann cells release a physiological cocktail of neurotrophic and wound healing factors that bind to the pure fibrin converting it from a 3-dimensional matrix that passively supports axon regeneration to one that actively promotes axon regeneration, while increasing the number of axons and the distance they regenerate into the fibrin and across the nerve gap [46-48].

The fibrin clot that forms within a nerve gap normally contains platelets that promoteaxon regeneration by several different mechanisms: (1) Fibrin within the PRP clot polymerizes creating a 3-dimensional fibrin matrix that supports but does on its own not promote axon regeneration. For the fibrin to promote axon regeneration, requires it must bind and interact with various neurotrophic factors released by the platelets and mesenchymal stem cells within the PRP clot. (2) Platelets and mesenchymal stem cells release neurotrophic and other factors that act directly on the axons [49-51]. (3) Platelets and mesenchymal stem cells release factors that cause the denervated Schwann cells of the distal nerve to proliferate and release of neurotrophic factors that promote regeneration of injured axons. (4) The mesenchymal stem cells within the PRP clot differentiate into Schwann cells within the nerve gap, where they release neurotrophic and other factors that promote regeneration of injured axons [52]. (5) Mesenchymal stem cells release angiogenic factors causing vascularization that is essential for axon regeneration $[53,54]$.

When nerve gaps are longer than $3 \mathrm{~mm}$, no fibrin clot forms because the fibrin flows away from the gap before it can polymerize within the gap. Without a fibrin scaffold to support and promote axon regeneration, no axons regenerate and there is no neurological recovery [4,55-63].

In the presence of a 3-dimensional matrix across a nerve gap, axon regeneration into the fibrin and across the nerve gap is directed across the nerve gap due to neurotrophic factors released from the Schwann cells in the distal nerve. The distal nerve stump acts as a point source of a physiological cocktail of neurotrophic factors [16,64]. As the neurotrophic factors diffuse sway from the end of the stump, and across the nerve gap, they form a concentration gradient of factors with its highest concentration at the end of the distal nerve stump, and its lowest concentration at the central nerve stump.

Growth cones extend fine processes that probe and sample the environment around them in search of factors to which they can adhere and that promote their elongation. In the absence of a regenerationpromoting environment there is little neurite outgrowth $[16,65]$. However, in the presence of a concentration gradient of neurotrophic factors, the axons regenerating out of the central nerve stump are directed up the concentration gradient of Schwann cell-released factors, across the gap, and to the distal nerve stump [1,66-69]. The regeneration of axons that reach the distal nerve stump continues to be directed into the distal nerve by the concentration gradient of Schwann cell-released factors ahead of them within the denervated distal nerve.

Various diffusible and substrate-bound molecules promote growth cone adhesion and elongation both in vivo and in vitro. Among these are laminin, Chondroitin Sulfate Proteoglycan (CSPG) [70], brainderived neurotrophic factor (BDNF) and netrin [67,69,71-74]. When these substances have a uniform distribution around a growth cone, they promote longer neurite outgrowth, but the neurites extend in a random manner. However, when these factors are presented as a substrate bound concentration gradient, the neurite and axons turn and regenerate up the concentration gradient $[67,69,71,75]$.

In vivo and in vitro, diffusible concentration gradients of neurotrophic and other factors may develop that both promote and direct axon regeneration. Some of these factors include acetylcholine, denervated muscle fiber-released factors, and Schwann cell-released neurotrophic factors [15,69,76-78]. Like substrate-bound factors, when these are distributed in a uniform concentration around a neuron in vitro, its neurites extend randomly in all directions [76]. However, when a concentration gradient of these factors is presented to a neurite growth cone by releasing them from the tip of a micropipette, the growth cone turns and moves up the concentration gradient $[15,76,79,80]$. Similarly, in vivo, as neurotrophic factors diffuse away from a length of denervated nerve or denervated muscle fibers, a diffusible concentration gradient of these factors is formed $[9,76]$. Regenerating axons respond by turning and growing up these diffusible concentration gradients of denervated target-derived factors that are effective in directing axon regeneration over distances of several centimeters [9,76,81-84].

\section{Bridging long nerve gaps - sensory nerve grafts}

When nerve gaps are longer than about $3 \mathrm{~mm}$, a fibrin scaffold does not form because the fibrin does not polymerize within the gap but becomes dispersed. Therefore, the Schwann cells within the central and distal nerve stump cannot migrant into the nerve gap, the axons have no scaffold on which to regenerate, and there is no neurological recovery $[4,55-58,60-63]$. To induce axons to regeneration across nerve gaps longer than $3-\mathrm{mm}$ requires the gaps be bridged with a conduit or material that both supports and promotes axon regeneration.

Axons are induced to regenerate across nerve gaps bridged with autologous nerve grafts of cutaneous saphenous or sural nerves $[61,85$ 87]. Autologous (allogeneic / homogenetic) nerve grafts have also been extensively studied in animal models [88-90]. However, sensory nerve grafts suffer from many limitations in their ability to promote axon regeneration and neurological recovery.

1. Sensory nerve grafts do not promote good motor axon regeneration because sensory and motor nerves express distinct sensory and motor phenotypes that support the regeneration or their specific axon phenotype [35,91-94]. Although motor nerve grafts are more effective in promoting axon regeneration across a nerve gap than sensory nerve grafts, they are not used because it is considered unethical to sacrifice a motor nerve function. 
2. The number of axons that regenerate and the extent of neurological recovery decrease with increasing gap length [95]. Although regeneration is good to excellent for bridged nerve gaps $<2 \mathrm{~cm}$ in length [95-101], it becomes increasingly limited as bridged gaps reach $4 \mathrm{~cm}$ in length [97,100], and decreases significantly with increasing graft length, with few axons regenerating across grafts of 8 $\mathrm{cm}$ in length $[95,98,99,102]$, and no regeneration is seen for gaps more than $10 \mathrm{~cm}$ in length [30,102-106].

3. The number and distance axons regenerate in association with sensory nerve grafts decreases with increasing time between nerve trauma and nerve repair $[97,107,108]$. Neurological recovery is good in $49 \%$ of patients who undergo a nerve repair $\leq 14$ days post trauma, with repairs performed 0.5-6 months post- lesion leading to reasonable motor recovery in $28 \%$ of patients, and the incidence of recovery decreases with greater delays [107]. There are only a few examples of neurological recovery for repairs performed $>12$ months post trauma [30,97,107,109-111].

4. The extent of neurological recovery decreases with increasing patient age, with best recovery being for patients up to 20-25 years of age [97,105,112-117]. Similar decreases in the efficacy of axon regeneration are seen for rats with increasing age [118].

5. The small graft diameters can lead to the grafts becoming ischemic and necrotic or fibrosed, which creates a toxic environment that inhibits axon regeneration $[119,120]$.

6. The small diameter of the sensory nerve compared to that of the mixed sensory/motor nerve being repaired, typically requires the use of multiple nerve grafts. Securing multiple grafts requires the use of large numbers of sutures to connect the grafts to the central and distal nerve stumps, and sutures often cause inflammation and scarring, both of which inhibit axon regeneration $[119,121]$.

7. Harvesting lengths of sensory nerve to use for the graft requires sacrificing a sensory nerve function creating a neurological deficit [122-125].

8. Histological examinations of sural nerve bridges show that the regenerating axons do not grow through the sural nerve graft in intimate association with the Schwann cells as they do when they regenerate through a motor nerve bridge [2,20,23,126-127]. Rather, the axons grow in association with the extracellular matrix sheathes of the Schwann cells $[1,4]$. Thus, sensory nerve grafts serve predominantly as a passive scaffold across which the axons regenerate, not as a pathway that actively promotes axon regeneration.

\section{Alternative tested techniques for bridging nerve gaps}

Biodegradable collagen tubes have been used to bridge peripheral nerves gaps for cat peripheral nerves. The collagen shows biocompatibility, and does not cause any adverse events, such as reactive or toxic alterations of the epineurium in contact with the implant [128]. Within one year of the nerve repair the nerve tube is replaced with a well vascularized connective tissue. In other experiments, transected peripheral nerves repaired with sutures (anastomosis of the nerve stumps), or with a collagen tube, show no difference in axon regeneration and neurological recovery [129]. These data show that the use of a collagen tube to bridge nerve gaps has no adverse influences on axon regeneration and neurological recovery [130].

Due to the limitations of sensory nerve grafts in inducing axon regeneration and neurological recovery many different materials have been tested for their ability to promote axon regeneration. Among these are: acellular nerve grafts [131-134], empty collagen tubes [135-138], collagen tubes filled with pure fibrin [139], nerve grafts plus fibrin [140], grafts of CNS tissue [141,142], dissociated Schwann cells [143-145], acellular autografts filled with Schwann cells [94], biocompatible non-collagen tubes [146], hydrogel tubes containing neurotrophic factors [134,106,147-155], empty Gore-Tex conduits [156,157], empty Gore-Tex tubes [156], Gore-Tex tubes filled with mesenchymal stem cells [158], synthetic hydrogel tubes $[98,145,159]$, empty conduits made of arteries, veins [160-162], muscle tubes [163], silicon conduits [161], conduits filled with pure fibrin, with and without added neurotrophic factors [164,165], collagen gel tubes [166], bioartificial nerve graft seeded with Schwann cells [167], Schwann cells modified to over-express specific growth factors [168-170], conduits of synthetic materials $[147,153,171,172]$, the infusion of antibodies [173], gradients of factors within tubes [174], allographs [175], factors that induce inflammation [149,176], pseudo nerves [177], alginate gel [178], biodegradable polymer tubes [179], tubes filled with platelet-rich plasma [180-182], and arteries, veins and muscle tubes [160,183,184]. None of these techniques induces more effective axon regeneration than autologous sensory nerve grafts [20,31,185-188]. Therefore, despite their significant limitation in inducing axon regeneration, sensory nerve grafts remain the "gold standard" for clinical peripheral nerve repair [3,99,110,106,148,189-193].

\section{Non-biological conduits to bridge nerve gaps}

Conduits (tubularization) that can be used to bridge nerve gaps have the advantage over nerve grafts in that they do not induce or permit the migration of fibroblasts into the injury site where they inhibit axon in-growth. In addition, tubularization serves to significantly reduce excessive collagen and scar formation, and prevent axons from escaping into surrounding tissues [56,194-196]. Finally, conduits allow Schwann cells to migrate into the nerve gap from the distal stump and together with the in-growing axons $[57,58,197,198]$.

Although conduits bridging nerve gaps have not yet proved very successful for promoting axon regeneration across gaps much longer than $2-\mathrm{cm}$ in length, they have been highly useful for investigating the sequence of cellular and molecular events during peripheral nerve regeneration $[57,177,199,200]$. The conduit captures the natural exudate of the nerve stumps (fibrin), which polymerizes into longitudinally oriented fibrin fibers that serves as a conductive scaffold along which Schwann cells migrate from both the central and distal nerve stumps $[57,58,177,197,201]$. Thus, conduits promote more extensive axon growth through a nerve gap than takes place in the absence of a tube and are used clinically for nerve defects up to 2-cm long $[86,194]$.

\section{Empty Nerve Tubes}

Within hours of implanting an empty tube it becomes filled with a fluid enriched with neurotrophic factors, extracellular matrix and other molecules which exert neurotrophic $[86,202,203]$, and neurotropic influences [204]. During days 3-7 the fluid is replaced by an acellular fibronectin positive, laminin negative fibrous matrix, which is critical for Schwann cell proliferation and for Schwann cells to migrate into the tube $[57,58,196,205,206]$. Fibroblasts and Schwann cells migrate from both nerve stumps within 2 weeks of implantation [144,207-209]. These tubes promote the regeneration of axons across gaps only up to $1-\mathrm{cm}$ long.

\section{3-Dimensional Matrix Filled Tubes}

Pre-filling tubes grafted into nerve gaps with various materials improves axon growth across nerve gaps. Gelfoam, (Pharmacia \& 
Upjohn), a collagen matrix [60] and artificial fibrin sponge (Gelaspon) [199-201,210] are suitable matrices that enhance the migration of Schwann cells [199] and subsequent axon in-growth. The success and the quality of regeneration across long nerve gaps are increased if the nerve gap-bridging conduit is filled with aligned collagen within laminin gels $[211,212]$. However, in spite of these approaches, axons do not regenerate through tubes longer than $2-\mathrm{cm}$.

\section{Addition of Cells to the Conduits Bridging Nerve Gaps}

Another approach has been the placement of a series of short lengths of nerve placed, several millimeters from one another across a nerve gap, referred to as "stepping stones" [213-215]. This technique induces axon regeneration across a nerve gap, but the lengths of nerve are not stable within the long tube due to the cells becoming ischemic, which creates a toxic environment within the tube, which inhibits axon regeneration [215].

An alternative approach is the addition of dissociated Schwann cells to the matrix within a tube bridging a nerve gap [144,208] or spinal cord gaps [216]. These Schwann cells secrete their neurotrophic factors which enhance axon regeneration through the tube [20,194,203,217]. One limitation with this approach is that Schwann cells have a limited distance they will migrate and a limited number of times they proliferate $[199,218,219]$. Thus, there is an insufficient concentration of Schwann cells within the conduit to promote axon regeneration. However, Schwann cell proliferation and migration can be increased by the application of insulin and insulin-like growth factor in the matrix within the nerve gap. The presence of these factors induces axons to regenerate across nerve gaps up to 2 -cm in length $[177,199,200]$.

\section{Addition of Neurotrophic Factors, Cytokines, and Other Factors to Conduits Bridging Nerve Gaps}

As indicated, insulin stimulates the regeneration of peripheral nerves [220] and when infused into a tube bridging a nerve gap enhances axon in-growth [221]. Insulin [199,200], and insulin-like growth factor-1 [220-224] within a bridging tube significantly increase the number of Schwann cells that migrate into the tube. Additional factors that induce Schwann cell proliferation are platelet-derived growth factor- $B$ (PDGF-B), acidic and basic fibroblast growth factors (b-FGF and a-FGF) [225], transforming growth factor (TGF- $\beta$ ) $[226,227]$ and neuregulins $[224,228,229]$. Axolemmal membrane also stimulates proliferation of cultured Schwann cells [230-234], while NGF added to a tube enhances axon ingrowth [235-237]. Multiple injections of a mixture of laminin, testosterone, ganglioside GM1 into the chamber also significantly increases the diameter and vascularization of nerve outgrowth [238]. Fibronectin-laminin and fibronectin [237] added to tubes enhances axon regeneration through a $1.8-\mathrm{cm}$ tube, predominantly by enhancing Schwann cell migration.

Axon regeneration could potentially be increased by the addition of other factors that promote nerve regeneration, such as the putative neurotrophic cytokines or neurokines [239,240]. These factors derived from versatile fibroblast growth factor family, are made up of 7 members: FGF-1-7, the transforming growth factors beta (TGF$\beta$ ), or the cholinergic differentiation factor (CDC)/ ciliary growth factor (CNTF)/ leukemia inhibitory factor (LIF) [241]. While some (FGF-1, FGF-2 (acidic FGF), CNTF, and LIF) seem to act as postnatal survival factors involved in the maintenance of distinct central and peripheral neurons, others seem to act as neuropoietic and/or neural differentiation factors (CDF/LIF, TGF- $\beta$ ) with defined spatiotemporal expression during early postnatal development [242] and could also play significant roles in promoting axon regeneration [240].

\section{Influence of Time Between Nerve Lesion and Repair on the Extent of Neurological Recovery}

The length of time between a nerve lesion and its repair significantly influences the extent of neurological recovery. Immediate anastomosis of a lesioned radial nerve leads to almost perfect neurological recovery [243]. However, anastomosis up to 14 days post injury leads to good recovery in only $49 \%$ of the patients, anastomosis from 14 days to 6 months following the lesion leads to reasonable neurological recovery in only $28 \%$ of the patients, while anastomosis after 10 months [30] leads to no neurological recovery.

Pre-degenerated nerve grafts provide more rapid initial axon ingrowth than fresh nerve grafts $[18,218,244,245]$, but do not influence the rate of regeneration $[218,244]$. The influence of pre-denervation is predominantly due to the proliferation of Schwann cells within the graft [246] and the increased concentration of neurotrophic factors released by the significantly increased number of Schwann cells [60,194,207,236,246-249]. Another approach for improving axon outgrowth is to use pre-denervate nerve that is cut and left in situ for 5 days to allow the Schwann cells to proliferate [250-253]. A length of the denervated nerve is then harvested, dissociated, and the dissociated Schwann cells injected into the tube bridging a nerve gap [254,255]. Although the presence of the Schwann cells improves the number of axons and distance they regenerate, there is no protocol for using this technique clinically. However, axons do not tend to regenerate through long-term denervated allographs [88], and as stated above, no neurological recovery take place if the distal nerve has been denervated for more than 10 months [30].

\section{Decrease in Neurological Recovery Decreases with Increasing Patient Age}

The success of axon regeneration across nerve gaps decreases with patient age, such that recovery is only relatively good for patients up to $20-25$ years of age $[97,112-115,117]$. For rats insulin-like growth factor 1 (IGF-1) is a potent neurotrophic factor that decreases in the distal portion of a transected nerve with increasing age [116]. Thus, while sciatic nerve axon regeneration is good in young rats it is poor in older rats. However, the application of locally delivered IGF-1 significantly improves axon number, diameter, and density. IGF-1 also significantly increases myelination and Schwann cell activity and preserves the morphology of the postsynaptic neuromuscular junction for both young and old rats [116].

\section{Inhibition of Axon Regeneration into the Distal Denervated Nerve Segment}

As stated earlier, following denervation, the Schwann cells in the distal nerve up-regulate the synthesis and release of a collection of neurotrophic and extracellular matrix factors. Among the extracellular matrix factors are laminin and chondroitin sulphate proteoglycans (CSPGs) [22,256,257]. While laminin and neurotrophic factors promote axon regeneration, CSPGs inhibits axon regeneration [70,258]. Although the overall balance of axon regeneration-promoting and -inhibiting favors axon regeneration, if the CSPG in a denervated nerve is eliminated, axon regeneration is faster and more extensive [26,258261]. Therefore, to enhance neurological recovery, lesioned axons must first be induced axons to regenerate across a nerve gap, and then down the distal nerve, which requires eliminating the factors that inhibit axon regeneration [258]. CSPGs can be eliminated by the application of the enzyme C-ABC that digests CSPG or by blocking its synthesis via intramuscular injections of $\beta$-D-xyloside [259,260]. $\beta$-D-xyloside acts 
by preventing the glycosylation of the proteoglycan side chains, which are required for inhibition of axon regeneration [257].

Virtually none of the techniques developed in animal models has been applied clinically because almost all require the use of materials, such as antibodies, enzymes, recombinant neurotrophic factors, materials for the tubes, and materials placed in the nerve tubes, which are not FDA approved. Obtaining FDA approval requires years of effort and is extremely expensive for each material or factor to be used. Finally, each factor must be tested separately and subsequently in various combinations prior to being tested clinically. Therefore, economical reasons prevent some of these techniques with great potential from being tested clinically.

\section{Pure Fibrin and Platelet-Rich Fibrin Glue for Peripheral Nerve Repair}

Fibrin glue is extensively used to repair lesioned peripheral nerves repair and sectioned central nervous system tissue [262-267]. It is also extensively used to anastomose lesioned peripheral nerves [190,262273]. In fact, fibrin glue is a better for anastomosing peripheral nerves than sutures [268,273-277]. Fibrin glue is both faster and easier to use than sutures, leads to more successful neurological recovery than sutures, and causes fewer complications, such as infections and inflammation [268,273-276].

Conduits composed of pure fibrin glue can be used to bridge $2 \mathrm{~cm}$ adult rat sciatic nerve gaps and promote axon regeneration, although in general the axons do not regenerate entirely across $2 \mathrm{~cm}$ fibrinfilled nerve gaps [123]. Although fibrin is part of the physiological mechanism by which the body attempts to promote axons to regenerate across a peripheral nerve gap, physiological fibrin within a nerve gap is not pure fibrin but fibrin plus platelets containing neurotrophic factor and wound healing factors $[3,265,276,278]$. These platelet-contained factors are released over about 4-7 days following platelet activation by injury. Thus, the autologous platelet-rich plasma enriches the fibrin with axon regeneration-promoting factors and promotes excellent axon regeneration $[3,262,269,277,279]$. This fibrin within conduits does not induce reliable promotion of axon regeneration across long nerve gaps, which requires fibrin to bind and interact with various neurotrophic and other factors to become effective in promoting axon regeneration.

\section{Schwann Cells and Bone Marrow-derived Mesenchymal Stem Cells}

Cellular prostheses composed of a resorbable guide seeded with autologous Schwann cells are an alternative for repairing long gaps in injured nerves, approaching the success of autografts [280,281]. However, conduits containing syngeneic Schwann cells did not improve the extent of axon regeneration with respect to acellular guides [280]. Transplanted Schwann cells survive within the nerve guide for 1-3 months after implantation, and an even larger number survive when they are autologous rather than syngeneic cells [280].

Filling conduits with primary Schwann cell-like differentiated bone marrow-derived mesenchymal stem cells (dMSC), and Schwann celllike differentiated adipose-derived stem cells (dASC) promote axon regeneration across $1 \mathrm{~cm}$ rat sciatic nerve gaps [122]. For mice, ASCs added to Matrigel (Sigma-Aldrich, St. Louis), a 3-dimensional matrix or extracellular matrix (ECM) components, within nerve gaps induce axon regeneration [282]. This may result from the cells expressing numerous genes of neurotrophins, particularly brain-derived neurotrophic factor (BDNF), and ECM proteins required for the nerve growth and myelination [282,283].
Spider silk conduits promote excellent axonal regeneration and functional recovery across adult rat peripheral recovery gaps [284] In vitro, synthetic basal lamina fibers induce neurite spreading and Schwann cell migration, suggesting that it may be beneficial in vivo in promoting axon regeneration and peripheral nerve repair [29]. Spider silk fibers, alone or supplemented with Schwann cells, facilitate Schwann cell proliferation and migration and promote extensive axon regeneration across $2 \mathrm{~cm}$ rat sciatic nerve gaps compared to gaps bridged with Matrigel within a conduit [285]. These data indicate that spider silk is a viable guiding material for Schwann cell migration and proliferation as well as for axonal re-growth in a long-distance model for peripheral nerve regeneration [285].

Matrices composed of Matrigel, microfilaments, and heregulin, which induce Schwann cell proliferation, synergistically induce significant improvements in the number and longitudinal organization of Schwann cells and axons across nerve gaps [286]. High molecular weight basic fibroblast growth factor support the regeneration of the injured axons across $15 \mathrm{~mm}$ long adult sciatic nerve across gaps bridged with silicone tubes filled with Matrigel or a mixture of Schwann Cells (SC) and Matrigel [287].

In an animal model and clinically, autogenous venous nerve conduits (AVNC) induce axons to regenerate across gaps of a maximum of $3 \mathrm{~cm}$ [288]. It has been claimed that the addition of autologous Schwann cells to these conduits increases the upper limit of nerve gaps across which AVNC conduits induce axon regeneration to $6 \mathrm{~cm}$ [288].

\section{Acellular Nerve Allografts}

Although nerve allografts promote axon regeneration across nerve gaps up to about $2 \mathrm{~cm}$ in length, nerve conduits of virtually no other composition induce axons to regenerate such a distance. The following section describes a number of different compositions of cells, factors and materials that have been shown to induce axons to regenerate across longer nerve gaps.

Acellular nerve allografts (ANAs) have been proposed as a good alternative to autografting and allotransplantation. ANAs have been shown to have similar capabilities as autografts in supporting axonal regeneration across short nerve gaps [125]. Although they promote axon regeneration, their efficacy depends on their ability to induce host tissue Schwann cell proliferation of [125]. Further, axonal regeneration and functional recovery induced by ANAs decreases as the graft length increases, while the performance of isografts is superior to ANAs at all lengths [125]. This is because of the development of senescent by long-time denervated host Schwann cells, which is indicated by the appearance of senescence associated beta-galactosidase, p16INK4A, and IL6 [125]. Since Schwann cells proliferation and migration decreases with increasing time of denervation, Schwann cell senescence plays a role in the limited axonal regeneration across nerve grafts of increasing gap lengths [289]. Finally, seeding ANAs with Schwann cells promotes a similar extent of axon regeneration across sciatic nerve gaps to that induced by allografts [290].

\section{Tissue-engineered Nerve Grafts}

Tissue-Engineered Nerve Grafts (TENGs) are an alternative to nerve autografts that are recognized as the "gold standard" for surgical repair of peripheral nerve gaps. TENGs typically consist of a neural scaffold included with support cells and/or growth factors, and represent a promising alternative to autologous nerve grafts for surgical repair of large peripheral nerve gaps [291]. TENGs have been constructed by incorporating autologous bone marrow Mesenchymal 
Stem Cells (MSCs) into a neural scaffold composed of a chitosan conduit inserted with poly(lactic-co-glycolic acid) (PLGA) fibers. Axon regeneration can be induced across $25-\mathrm{mm}$-long canine tibial nerve gaps by treating PLGA nerve conduits with pulsed plasma and Ciliary Neurotrophic Factor (CNTF) plus chitosan [292]. However, in general their influence is not more extensive than that induced by autologous nerve grafts [292]. At 12 months post-surgery in which a $6 \mathrm{~cm}$ long dog sciatic nerve gaps were bridged by TENGs, of chitosan/PLGA scaffolds, or nerve autografts, the TENGs induced similar axon regeneration results to that of autografts, but better than those induced by scaffolds alone [291,293].

The transplantation of adult neural stem cells (ANSCs) inside an autologous venous graft across a pig $30 \mathrm{~mm}$ long nerve gap in adult pigs induces axon regeneration and neurological function [294,295]. This is due to ANSCs increasing CNPase expression, indicating the activation of intrinsic Schwann cells [295].

Poly epsilon-caprolactone (PCL) conduits for rat sciatic nerve gaps induce axons to regenerate across gaps up to $1 \mathrm{~cm}$ in length $[125,289]$.

Repair of large nerve defects with ANAs is an appealing alternative to autografting and allotransplantation. Although ANAs have similar influences to autografts in supporting axonal regeneration across short gaps, they are not effective for larger nerve defects [289,296,297]. ANAs depend on the addition of Schwann cells and their extensive proliferation to support axonal regeneration. However, the longer the ANA the greater Schwann cell proliferative that is required, which can create stress in those Schwann cells and their subsequent senescence [289]. Thus, ANAs plus Schwann cells are less effective in inducing axon regeneration across bridged nerve gap as the gap increase in length from 2 to 4 to $6 \mathrm{~cm} \mathrm{[289].} \mathrm{However,} \mathrm{the} \mathrm{extent} \mathrm{of} \mathrm{axon} \mathrm{regeneration}$ can be enhanced if the Schwann cells are transfected with the ciliary neurotrophic factor (CNTF) gene to increase their neurotrophic influence on the axons [298].

Gene therapy with vascular endothelial growth factor (VEGF) significantly improves axon regeneration, neuronal survival, and muscle activity [124]. Granulocyte colony-stimulating factor (G-CSF) synergizes with VEGF to improve the functional outcome after sciatic nerve transection [124]. However, treating animals with both G-CSF plus VEGF significantly increases the number of regenerated myelinated fibers, blood vessels, the number of neurons in the DRG and motor neurons in the spinal cord, and recovery of motor function than either alone. This suggests that these factors act synergistically and optimized the nerve repair potential, improving axon regeneration after a transection lesion [124].

\section{Electrical Stimulation}

Electrical stimulation of the transected axons induces a 2.3 -fold increase in axon sprouting vs. unstimulated control neurons [299]. It also increases by $34 \%$ the number of neurons that extend axons $[300,301]$ and speed of axon regeneration [302]. This influence is in part due to electrical stimulation promoting both Schwann cell migration and proliferation, and by acting directly on neurons to induce them to increase the distance axons are extended [303]. Electrical stimulation also gives rise to significantly increase in Calcitonin Gene-Related Peptide (CGRP)-immunolabeled Schwann cells, and the recruitment of a significantly higher number of macrophages to the distal portion of the transected sciatic nerve [304]. Electrical stimulation also induces the Schwann cells of the distal portion of the transected nerve to upregulate their synthesis and release of neurotrophic factors that act on the injured axons to promote regeneration that would otherwise not take place $[305,306]$. While electrical stimulation is usually applied precutaneously for facilitating peripheral nerve regeneration, when applied directly to rat sciatic nerves with 8 -mm gaps, it induces a $50 \%$ increase in the number of axons that regenerate vs. control animals [307,308].

Part of the influence of electrical stimulation is attributed to inducing the stimulated neurons to up-regulate their levels of cyclicAMP and a number of growth-associated genes [306]. In turn, this increased cAMP concentration induces motor neurons to up regulate their expression and synthesis of the endogenous neurotrophic factor BDNF and its trkB receptor mRNA [309-313]. This induced increase in endogenous BDNF increases the extent of axon regeneration.

Both clinically and in animal models, electrical stimulation also shortens the onset time of axon outgrowth, increase the speed of axon regeneration [301,309,314-316], increase the distance axons regenerate across nerve gaps [317], and increase the accuracy of sensory vs. motor axon innervation of their appropriate distal nerves [41,315,318]. Even one hour of $20 \mathrm{~Hz}$ electrical stimulation of the proximal nerve stump prior to a nerve repair enhances the rate of axon regeneration [315].

In addition to electrical stimulation of the central nerve stump of a transected peripheral nerve, the use of electrically conductive biodegradable hydrogel consisting of oligo (polyethylene glycol) fumarate (OPF) and polypyrrole (PPy) increases neurite outgrowth [319], and when containing single-walled carbon nanotubes (SWCNT) support the viability of Schwann cells within the nerve gap [303]. Thus, an electrically-conductive SWCNT collagen I-Matrigel biomaterial may be suitable for neural tissue engineering and by sustaining populations of Schwann cells [303]. Similarly, electrical stimulation via an electrically conductive biodegradable polymer composite, enhances the rate of neurite outgrowth from cultured PC12 cells [315]. However, it is not known whether combining electrical stimulation with other nerve repair techniques may further enhance the rate and extent of axon regeneration and neurological recovery.

Combining adipose-derived stem cells (ADSC) with ANA increases axon regeneration across $10 \mathrm{~mm}$ long nerve gaps, compared to axon regeneration induced by ANA alone [320]. This is potentially due to the release by ADSCs of neurotrophic factors [321].

By 3 months post-repair, Bone-Marrow-Derived Mesenchymal Stem Cells (BMSCs) and Adipose-Derived Mesenchymal Stem Cells (ADSCs) incorporated into acellular nerve grafts promote more extensive sciatic nerve regeneration and functional recovery than is induced by autografting and Schwann cells alone, and more than that induced by acellular nerve allografting alone [322]. Similarly, Schwann cells derived from induced Bone Marrow Stromal Cells (BMSCs) may be useful for promoting axon regeneration across peripheral nerve gaps [323]. Combining BMSCs with laminin-modified chitosan multi-walled nerve conduits bridging $10 \mathrm{~mm}$ long rat sciatic nerve gaps, the number of axons that regenerate increases, as does the muscle mass. These data suggest that BMSCs suppress neuronal cell death and promote axon regeneration by suppressing the inflammatory and fibrotic response induced by chitosan after long-term implantation [324].

Polyvinyl chloride (PVC) tubes implanted within a 19-mm long sciatic nerve gaps become surrounded by collagen, which remains after the PVC tube is removed. These collagen tubes induce similar axon regeneration to that induced by of autologous nerve [130].

\section{Macrophages}

Following nerve injury there is a slow increase in the concentration of macrophages in the region of the nerve injury [325-327]. This 
increase persists up to 28 days and is accompanied by an up-regulation of inflammatory mediators, including oncomodulin. Intraganglionic cAMP injection also resulted in an increase in macrophages [327].

In vitro arecoline significantly promotes the survival and outgrowth of cultured Schwann cells compared to cells in control cultures. In vivo the arecoline significantly increases the number and the density of myelinated axons compared to controls. In addition, the number of macrophages recruited in the distal sciatic nerve increases as the concentration of arecoline is increased. Thus, arecoline stimulates local inflammatory conditions, thereby improving axon regeneration and the recovery from severe peripheral nerve injury [328].

The rate of axon regeneration across $15 \mathrm{~mm}$ rat sciatic nerve gaps is faster if macrophages with a pro-healing (M2a and M2c phenotype) vs. pro-inflammatory phenotype are combined with polymeric nerve tubes [329]. This can be accomplished by the local delivery of either Interferon-gamma (IFN-gamma) or Interleukin-4 (IL-4), within the tubes [329]. The neuron-macrophage interactions involved in eliciting a pro-regenerative phenotype in macrophages may be a novel target to induce long-lasting regenerative processes after axonal injuries in the CNS [327].

\section{Commercial Nerve Gap Conduits}

Commercial conduits that are effective in inducing axon regeneration across nerve gaps are composed of type I collagen, Integra NeuraGen (NG) nerve guides, and processed rat allografts, which have similar efficacy to AxoGen's Avance human decellularized allograft $[134,330]$. For 14-mm sciatic nerve gaps, the efficacy of isografts is superior to processed allograft, which is more effective than the NeuraGen grafts. However, for a 28-mm graft model, isografts are more effective than processed allografts $[134,330]$.

\section{3-Dimensional Scaffolds}

Filling a nerve gap with a 3-dimensional Matrigel promotes axon regeneration entirely across gaps [281,331]. This influence is increased if Schwann cells overexpressing high molecular weight FGF2 is combined with the Matrigel [287]. An alternate approach is to use conduits to bridge nerve gaps that contain intraluminal guidance structures, vs. unstructured conduits. Such conduits increase both Schwann cell migration and axon regeneration across nerve gaps [193].

The Schwann cell basal lamina of the ECM promotes nerve regeneration following nerve transection by promoting Schwann cell colonization and promoting axonal guidance due to the presence of laminin within the ECM. Thus, axon regeneration can be promoted by mimicing the native basal lamina by using basal lamina proteins from BD Matrigel (growth factor-reduced) extracted and electrospun to deposit nonwoven nanofiber mats. Such fabricated nanofiber mats support the attachment of cultured embryonic chick DRG explants, the elongation of neurites, and the migration of Schwann cells in a similar fashion compared to electrospun collagen type-I fibers repair. The extension of neurites and Schwann cell replication is significantly increased by the presence of nanorough surface features repair [29].

The Schwann cells in the denervated distal nerve release neurotrophic factors that promote axon regeneration, but also release ECM components that promote and inhibit axon regeneration, [20,22$26,332,333]$. Thus, regeneration through the distal nerve is a balance of the influences of factors that both promote and inhibit regeneration. If the Schwann cells are present, such as after a simple nerve crush, virtually $100 \%$ of the axons regenerate and they innervate all the denervated synaptic sites. If the Schwann cells within the distal nerve pathway are killed, leaving only the ECM intact, the number of axons that regenerates to their targets decreases by $94 \%$. This is because the factors required to trigger the regenerating axons to branch at ECM branch points are missing, axons do not branch, and therefore each axon reinnervates only a single denervated muscle fiber. Thus, Schwann cells along the distal nerve pathway and a diffusible the cocktail of Schwann cell-released factors are critical for promoting axon regeneration and branching and good reinnervation of distant denervated nerve targets [1].

One mechanism used to bridge nerve gaps is laminin and Laminin-Polycaprolactone (PCL) blend of nanofibers fabricated to mimic peripheral nerve basement membrane. When the nanofibers are oriented parallel to the orientation of the nerve, there is extensive axon regeneration, vs. little axon regeneration when the nanofibers have a random orientation. However, under both circumstances axon regeneration is better than through an empty conduit [334].

\section{Concentration Gradients of Factors}

The uniform distribution of Schwann cell released neurotrophic factors (peripheral nerve conditioned medium, CM) around neurons in culture medium induces both adult sensory and motor neurons to extend axons 10-fold longer than in the absence of these factors $[65,335]$. However, presentation of a concentration gradient of CM across nerve gaps, or applying it directly to the central stump of a nerve, increased significantly the number of axons that regenerated, and the gradients of CM factors was effective across distances of $4-\mathrm{cm}$ in length [16,249,336,337].

Mini osmotic pumps (Alzet Pump, Durect Corp) have been loaded with $\mathrm{CM}$ and a catheter attached to the pump. When the open end of the catheter is positioned at the distal end of the nerve gap, the pumps (Alzet 2004, Durect Corp.) infuses CM into the matrix within the gap at a constant rate of $0.5 \mu \mathrm{l}$ per hour for 4 weeks. Diffusion of the factors in the CM away from the end of the catheter and into the nerve gap creates a concentration gradient of the factors, with its highest concentration at the tip of the catheter, and it's lowest at the central nerve stump. Such diffusible concentration gradients of neurotrophic factors induce axons to regenerate up the gradient and towards the distal nerve stump. This technique increases by $50 \%$ the number of axons that regenerate across the $4 \mathrm{~cm}$ long gaps compared to control preparations without $\mathrm{CM}$ infusion $(\mathrm{N}=6)$ [337].

$\mathrm{CM}$ is obtained by placing a 2-cm length of sciatic nerve in $3 \mathrm{ml}$ of culture medium for 5 days. During this time, the Schwann cells synthesized and released various neurotrophic as they do physiologically in situ. The CM is then harvested, filtered to remove cellular debris and maintains it biologically activity when kept at $37^{\circ} \mathrm{C}$ for more than 3 months, or for several years when kept at $-85^{\circ} \mathrm{C}$ (Kuffler, unpublished observations).

Axon regeneration is also directed by bound concentration gradients of nerve growth factor (NGF) within a conduit bridging a nerve gap [84,338-341]. Herein, combining differential adsorption of NGF/silk fibrin (SF) coating, the gradient of NGF-immobilized membranes (G-Ms) and nanofibrous nerve conduits (G-nNCs) can be fabricated. Furthermore, 12 weeks after implantation in rats with a $14 \mathrm{~mm}$ gap of sciatic nerve injury, the sciatic nerve function index (SFI), compound muscle action potentials (CMAPs), total number of myelinated nerve fibers, thickness of myelin sheath are similar to G-nNCs and autografts, with the G-nNCs having a higher density of axons than the autografts. These results demonstrate the significant role of the introducing NGF gradients into scaffolds in promoting nerve regeneration [84]. Similarly, 
diffusible concentration acetylcholine direct the outgrowth of DRG neurons in vitro [78].

\section{Dissociated Schwann Cells within the Fibrin Matrix}

As stated earlier, dissociated Schwann cells from pre-denervated peripheral nerve release neurotrophic factors that induce axons to regenerate across nerve gaps [255]. Similarly, Schwann cells dissociated from a freshly removed nerve enhance axon regeneration across nerve gaps [252,342].

\section{Mesenchymal Stem Cells}

The transplantation of human embryonic stem cell-derived mesenchymal stem cells (hESC-MSCs) into a $2 \mathrm{~mm}$ long sciatic nerve gap induced axon regeneration across the gap and recovery in nerve function $[343,344]$. It has been proposed that hepatocyte growth factor and insulin-like growth factor-binding protein-1 released from the hESC-MSCs are responsible for promoting the axon regeneration [344].

\section{Additional Methods that Increase the Rate and Extent of Axon Regeneration}

Several techniques have been shown clinically and in animal models to enhance the number of axons that regenerate and the distance they regenerate. Among these are electrical stimulation of the central nerve stump, and the administration of the immunosuppressant FK506 (tacrolimus), and the administration of $\beta$-D-xyloside.

\section{Immunosuppressants}

Animal model studies have shown that motor nerve grafts induce axons to regenerate significantly longer distances than sensory nerve grafts $[33,99]$. Typically such studies involved the use of motor grafts harvested another animal of the same or different species, i.e. xenographs or allographs respectively. To use such grafts requires the use of an immunosuppressive agent to prevent the foreign nerve graft from being rejected by the immune system of the host animal, and one immunosuppressants used was FK506 [345]. During these studies it was observed that the administration of FK506, at concentrations far below that required for its immunosuppressant function $(5 \mathrm{mg} / \mathrm{kg} /$ day down to $0.05 \mathrm{mg} / \mathrm{kg} /$ day for 4 weeks), influenced axon regeneration. FK506 (1) induces a 2-fold increase in the number of axons that regenerate, (2) increases the speed of axon regeneration across $4 \mathrm{~cm}$ gaps, (3) increases the number of myelinated axons by $40 \%$, (4) significantly increases myelin thickness, (5) increases the specificity of sensory and motor target reinnervation, and (6) increases the extent of neurological recovery [346-356].

In a nerve repair study on an animal model, FK506 was administered directly to the severed ends of axons within an inside-out vein graft used to bridge nerve gaps. An advantage of administering FK506 locally like this is that it avoids systemic exposure to FK506 that may be toxic. Delivered in this form, FK506 increases both the rate and extent of axon regeneration [357]. FK506 also reduces by half the time to achieve neurological recovery, although it does not induce a significant improvement of long-term neurological recovery compared to control animals $[358,359]$.

Clinically, FK506 has also been tested for its influence on axon regeneration when administered at 5 and $8 \mathrm{ng} / \mathrm{ml} / / \mathrm{kg} /$ day for a total of 60 days. Clinically FK506 induces more rapid axon regeneration than is seen in control patients [360]. Similar to the results from animal model studies, the final extent of recovery of neurological function is not better than that of patients who do not receive FK506 [360].
The influences of FK506 in increasing the rate and extent of axon regeneration can be enhanced if FK506 is administered in conjunction with other factors. Thus, the simultaneous administration of FK506, NGF and bFGF within a nerve conduit bridging a nerve gap leads to axons regenerating longer distances than when these factors are administered alone [358,361-364].

The extent of restoration of neurological function decreases with increasing time between nerve trauma and repair. Nerves that are denervated for 4 or more months are referred to as chronically denervated nerves and they support little or no axon regeneration. This is because the Schwann cells of such nerves no longer synthesize and release the neurotrophic factors that are required to promote axon regeneration. However, the administration of FK506 increases the number of axons that regenerate into and though chronically denervated nerves [358]. This is best explained by explained by results showing that the FK506 derivative, jnj460, acts on Schwann cells altering their gene expression causing them to release factors that promote neurite outgrowth from DRG neurons in vitro. These observations argue that FK506 or its analogues should be administrated in clinical cases where a nerve repair must be performed long after nerve trauma.

\section{$\beta$-D-xyloside and Suppression of the Synthesis of Chondroitin Sulfate Proteoglycan (CSPG)}

Following a nerve crush or transection, Schwann cells exhibit a 7 -fold increase in their synthesis of chondroitin sulfate proteoglycan (CSPG) . CSPG binds to and inhibits the neurite-promoting activity of laminin, thus retarding axon regeneration. $\beta$-D-xyloside is an inhibitor of the synthesis of CSPG, and its administration reduces CSPG by $90 \%$ within 4 days and subsequent completely disappearance of CAPG . As the concentration of CSPG within a denervated distal portion of a nerve decreases, so does its regeneration-inhibiting influence, which results in a $60 \%$ increase in the rate and distance an axon regenerates [26].

The mechanisms by which PRP, electrical stimulation, $\beta$-Dxyloside, FK506 and other methods enhance axon regeneration differ. This suggests that the simultaneous administration of $\beta$-D-xyloside and PRP would have additive effects and promote more extensive axon regeneration than when they are administered singly, but this has not yet been tested. Therefore, studies are needed in which these different methods are applied simultaneously to determine whether when combined, more axons regenerate longer distances and give rise to more extensive recovery of neurological function than when the axons are exposed to any one singly.

\section{Novel Clinically Effective Nerve Repair Techniques}

Recently three novel nerve repair techniques have been tested that induce axon regeneration under conditions where no other technique is effective. Each technique is based on the physiological method by which axons are promoted to regenerate across short ( $<3 \mathrm{~mm}$ long nerve gaps. The three techniques have been tested clinically. The techniques involve bridging nerve gaps with a collagen tube containing: (1) a sensory nerve graft plus pure fibrin, (2) a collagen tube containing a sensory nerve graft plus platelet-rich plasma, and (3) a collagen tube containing only platelet-rich plasma [39]. Figure 1 shows a schematic of these techniques. Figure 2 shows a nerve that had an 8-cm long nerve gap repaired with a collagen tube plus a single sensory nerve graft filled with platelet-rich plasma. The repaired nerve induced the recovery of both sensory and motor function [39]. All three techniques induced more extensive axon regeneration and neurological recovery than the standard clinical nerve gap repair method, which uses only a sensory nerve graft. 
Citation: Kuffler DP (2015) Promoting Axon Regeneration and Neurological Recovery Following Traumatic Peripheral Nerve Injuries. Int $\mathrm{J}$ Neurorehabilitation 2: 148. doi:10.4172/2376-0281.1000148

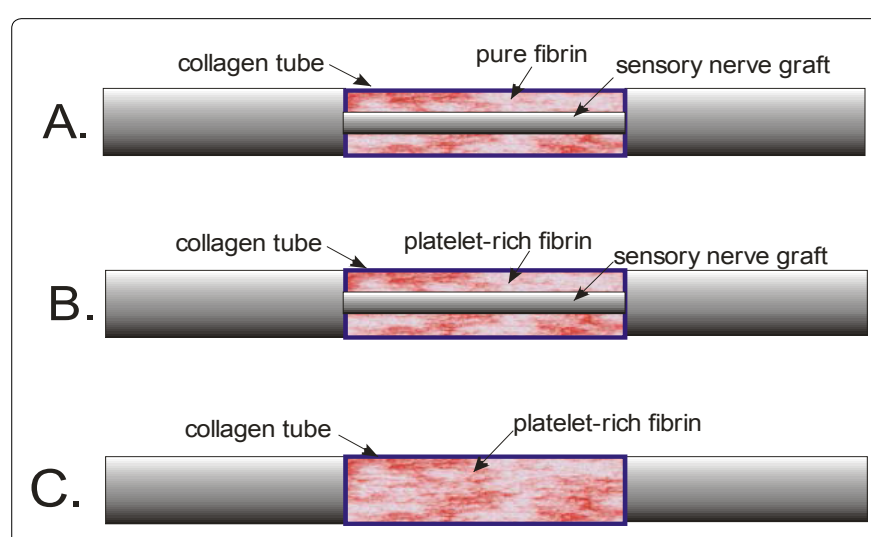

Figure 1: Three novel clinically applied techniques that induce extensive axon regeneration and neurological recovery under conditions where sensory nerve grafts are not effective. Such techniques induce axons to regenerate across nerve gaps up to $16 \mathrm{~cm}$ in length, when nerve repairs are performed up to 3.25 years post nerve trauma, and for patients up to 58 years of age.

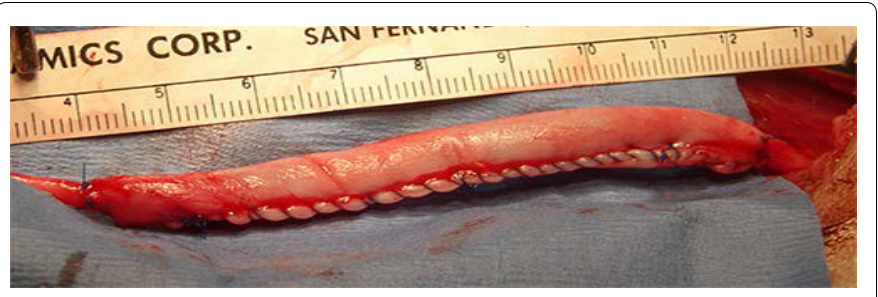

Figure 2. An $8 \mathrm{~cm}$ long peripheral nerve gap bridged with a collagen tube filled with autologous platelet-rich plasma. Axons regenerated entirely across the gap, through the distal nerve, and reestablished neurological function.

Platelet-rich plasma can be obtained by separating it from a patient's or animal's own whole blood in the operating room using differential centrifugation of the whole blood. This separation is a routinely used in many operating rooms, for the repair of damaged dura, soft tissue, or in orthopedic surgery where as a glue to hold bone chips in place. It has also been found that PRP enhances the extent of axon regeneration across adult rat nerve gaps of $1.5 \mathrm{~cm}$.

Bridging nerve gaps with all three of these novel techniques leads to axon regeneration and neurological recovery under conditions where sensory nerve grafts are not effective: across nerve gaps up to $16 \mathrm{~cm}$ in length, for nerve repairs performed up to 3 years post nerve trauma, and for patients up to 50 years of age [39]. Further studies are required with these techniques to determine whether the techniques can be improved to induce more axons to regenerate longer distances more reliably can to restore more extensive $\mathrm{d}$ neurological recovery.

\section{Conclusions}

A variety of techniques increase the number of axons and the distance axons regenerate across a nerve gap and into the distal nerve. Sensory nerve grafts are the standard clinical technique, but have many limitations in inducing axons to regenerate across gaps $>2 \mathrm{~cm}$ in length. Other techniques include seeding nerve gaps with Schwann cells, creation of concentration gradients of Schwann cellreleased factors $(\mathrm{CM})$ the nerve gap, enhancing the rate of axon regeneration with FK506 and eliminating regeneration inhibiting factors (CSPG). However, additional techniques are effective, such as elevating c-AMP in neurons, providing neurotrophic factors, and gene manipulations that enhance axon regeneration. Recently three novel clinically applicable nerve repair techniques have been shown to induce axon regeneration and neurological across longer nerve gaps, for nerve repairs performed many years post nerve trauma and in older patients, conditions under which no other technique is effective. However, since various other techniques induce axon regeneration via a different mechanism, it is reasonable to assume that several techniques could be used together with these novel techniques to induce more reliable and extensive axon regeneration and neurological recovery.

\section{References}

1. Kuffler DP (1986a) Accurate reinnervation of motor end plates after disruption of sheath cells and muscle fibers. J Comp Neurol 250: 228-235.

2. Madison RD, Archibald SJ, Brushart TM (1996) Reinnervation accuracy of the rat femoral nerve by motor and sensory neurons. J Neurosci 16: 5698-5703.

3. Dagum AB (1998) Peripheral nerve regeneration, repair, and grafting. J Hand Ther 11: $111-117$.

4. Kuffler DP (1987b) Long-distance regulation of regenerating frog axons. J Exp Biol 132: 151-160.

5. Fawcett JW, Keynes RJ (1990) Peripheral nerve regeneration. Annu Rev Neurosci 13: 43-60.

6. Abernethy DA, Rud A, Thomas PK (1992) Neurotropic influence of the dista stump of transected peripheral nerve on axonal regeneration: absence of topographic specificity in adult nerve. J Anat 180 ( Pt 3):395-400.

7. Allan $\mathrm{CH}$ (2000) Functional results of primary nerve repair. Hand Clin 16: 67-72.

8. Burnett MG, Zager EL (2004) Pathophysiology of peripheral nerve injury: a brief review. Neurosurg Focus 16: E.

9. Kuffler DP (1986c) Isolated satellite cells of a peripheral nerve direct the growth of regenerating frog axons. J Comp Neurol 249: 57-64.

10. Kuffler DP (1989) Regeneration of muscle axons in the frog is directed by diffusible factors from denervated muscle and nerve tubes. J Comp Neurol 281: 416-425.

11. Clarke D, Richardson P (1994) Peripheral nerve injury. Curr Opin Neurol 7 : 415-421.

12. Sahenk Z, Seharaseyon J, Mendell JR (1994) CNTF potentiates peripheral nerve regeneration. Brain Res 655: 246-250.

13. Levy D, Kubes P, Zochodne DW (2001) Delayed peripheral nerve degeneration regeneration, and pain in mice lacking inducible nitric oxide synthase. Neuropathol Exp Neurol 60: 411-421.

14. Madduri S, Gander B (2010) Schwann cell delivery of neurotrophic factors for peripheral nerve regeneration. J Peripher Nerv Syst 15: 93-103.

15. Kuffler DP (1994a) Promoting and directing axon outgrowth. Mol Neurobiol 9 233-243.

16. Pérez NL, Sosa MA, Kuffler DP (1997a) Growth cones turn up concentration gradients of diffusible peripheral target-derived factors. Exp Neurol 145: 196202.

17. Zheng M, Kuffler DP (2000) Guidance of regenerating motor axons in vivo by gradients of diffusible peripheral nerve-derived factors. J Neurobiol 42: 212 219.

18. Lewin-Kowalik J, Marcol W, Larysz-Brysz M, Wolwender K, Pietrucha-Dutczak M, Gorka D (2002) Pre-degenerated peripheral nerve extracts applied to the proximal stump of transected sciatic nerve enhance both regeneration and autotomic behavior in rats. Med Sci Monit 8:BR414-420.

19. Evans GR, Brandt K, Ang KK, Cromeens D, Peden E, et al. (1997) Periphera nerve regeneration: the effects of postoperative irradiation. Plast Reconstr Surg 100: $375-380$.

20. Brushart TM, Gerber J, Kessens P, Chen YG, Royall RM (1998) Contributions of pathway and neuron to preferential motor reinnervation. J Neurosci 18: 8674-8681.

21. Chen YG, Brushart TM (1998) The effect of denervated muscle and Schwann cells on axon collateral sprouting. J Hand Surg Am 23: 1025-1033.

22. Zuo J, Hernandez YJ, Muir D (1998b) Chondroitin sulfate proteoglycan with neurite-inhibiting activity is up-regulated following peripheral nerve injury. $J$ Neurobiol 34:41-54. 
Citation: Kuffler DP (2015) Promoting Axon Regeneration and Neurological Recovery Following Traumatic Peripheral Nerve Injuries. Int $\mathrm{J}$ Neurorehabilitation 2: 148. doi:10.4172/2376-0281.1000148

Page 10 of 17

23. Madison RD, Archibald SJ, Lacin R, Krarup C (1999) Factors contributing to preferential motor reinnervation in the primate peripheral nervous system. $J$ Neurosci 19: 11007-11016.

24. Le TB, Aszmann O, Chen YG, Royall RM, Brushart TM (2001) Effects of pathway and neuronal aging on the specificity of motor axon regeneration. Exp Neurol 167: 126-132

25. Krarup C, Archibald SJ, Madison RD (2002) Factors that influence periphera nerve regeneration: an electrophysiological study of the monkey median nerve. Ann Neurol 51: 69-81.

26. Zuo J, Neubauer D, Graham J, Krekoski CA, Ferguson TA, et al. (2002) Regeneration of axons after nerve transection repair is enhanced by degradation of chondroitin sulfate proteoglycan. Exp Neurol 176: 221-228.

27. Madduri S, Papaloïzos M, Gander B (2009) Synergistic effect of GDNF and NGF on axonal branching and elongation in vitro. Neurosci Res 65: 88-97.

28. Fansa H, Keilhoff G (2004) Comparison of different biogenic matrices seeded with cultured Schwann cells for bridging peripheral nerve defects. Neurol Res 26: 167-173.

29. de Guzman RC, Loeb JA, VandeVord PJ (2010) Electrospinning of matrigel to deposit a basal lamina-like nanofiber surface. J Biomater Sci Polym Ed 21: $1081-1101$.

30. Shergill G, Bonney G, Munshi P, Birch R (2001) The radial and posterior interosseous nerves. Results fo 260 repairs. J Bone Joint Surg Br 83: 646-649.

31. Shirley DM, Williams SL, Covey JF, Santos PM (1996) A functional model of nerve repair. Reanastomosis vs entubulation repair. Arch Otolaryngol Head Neck Surg 122: 785-788.

32. Menovsky T, van der Bergh Weerman M, Kubista OL, Bartels RH, van Overbeeke JJ (1999) End-to-end versus peripheral nerve graft repair of the oculomotor nerve in rats: A comparative histological and morphometric study. Microsurgery 19: 392-400.

33. Brushart TM, Mathur V, Sood R, Koschorke GM (1995) Joseph H. Boyes Award. Dispersion of regenerating axons across enclosed neural gaps. J Hand Surg Am 20: 557-564.

34. Höke A, Redett R, Hameed H, Jari R, Zhou C, et al. (2006a) Schwann cells express motor and sensory phenotypes that regulate axon regeneration. $J$ Neurosci 26: 9646-9655.

35. Abdullah M, O'Daly A, Vyas A, Rohde C, Brushart TM (2013) Adult motor axons preferentially reinnervate predegenerated muscle nerve. Exp Neurol 249: 1-7.

36. Brushart TM, Aspalter M, Griffin JW, Redett R, Hameed H, et al. (2013) Schwann cell phenotype is regulated by axon modality and central-peripheral location, and persists in vitro. Exp Neurol 247: 272-281.

37. Rende M, Granato A, Lo Monaco M, Zelano G, Toesca A (1991) Accuracy of reinnervation by peripheral nerve axons regenerating across a $10-\mathrm{mm}$ gap within an impermeable chamber. Exp Neurol 111: 332-339.

38. Kuffler DP, Reyes O, Sosa IJ, Santiago-Figueroa J (2011) Neurological recovery across a $12-\mathrm{cm}$-long ulnar nerve gap repaired 3.25 years post trauma: case report. Neurosurgery 69: E321-1326.

39. Al-Majed AA, Neumann CM, Brushart TM, Gordon T (2000b) Brief electrical stimulation promotes the speed and accuracy of motor axonal regeneration. $J$ Neurosci 20:2602-2608.

40. Brushart TM, Jari R, Verge V, Rohde C, Gordon T (2005) Electrical stimulation restores the specificity of sensory axon regeneration. Exp Neurol 194: 221-229.

41. Franz CK, Singh B, Martinez JA, Zochodne DW, Midha R (2013) Brief transvertebral electrical stimulation of the spinal cord improves the specificity of femoral nerve reinnervation. Neurorehabil Neural Repair 27: 260-268.

42. Chen HH, Liu HM (1994) The use of collagen polymer tube and fibrin clot in peripheral nerve repair. Proc Natl Sci Counc Repub China B 18: 58-63.

43. Reyes O, Sosa I, Kuffler DP (2005) Promoting neurological recovery following a traumatic peripheral nerve injury. P R Health Sci J 24: 215-223.

44. Nurden AT, Nurden P, Sanchez M, Andia I, Anitua E (2008) Platelets and wound healing. Front Biosci 13: 3532-3548.

45. Iwakawa M, Mizoi K, Tessler A, Itoh $Y$ (2001) Intraspinal implants of fibrin glue containing glial cell line-derived neurotrophic factor promote dorsal root regeneration into spinal cord. Neurorehabil Neural Repair 15: 173-182.
46. Jubran M, Widenfalk J (2003) Repair of peripheral nerve transections with fibrin sealant containing neurotrophic factors. Exp Neurol 181: 204-212.

47. Galla TJ, Vedecnik SV, Halbgewachs J, Steinmann S, Friedrich C, et al. (2004) Fibrin/Schwann cell matrix in poly-epsilon-caprolactone conduits enhances guided nerve regeneration. Int J Artif Organs 27: 127-136.

48. Cho HH, Jang S, Lee SC, Jeong HS, Park JS, et al. (2010) Effect of neuralinduced mesenchymal stem cells and platelet-rich plasma on facial nerve regeneration in an acute nerve injury model. Laryngoscope 120: 907-913.

49. Dadon-Nachum M, Sadan O, Srugo I, Melamed E, Offen D (2011) Differentiated mesenchymal stem cells for sciatic nerve injury. Stem Cell Rev 7: 664-671.

50. Jackson WM, Alexander PG, Bulken-Hoover JD, Vogler JA, Ji Y, et al. (2013) Mesenchymal progenitor cells derived from traumatized muscle enhance neurite growth. J Tissue Eng Regen Med 7: 443-451.

51. Ladak A, Olson J, Tredget EE, Gordon T (2011) Differentiation of mesenchymal stem cells to support peripheral nerve regeneration in a rat model. Exp Neurol 228: 242-252.

52. Kurita J, Miyamoto M, Ishii Y, Aoyama J, Takagi G, et al. (2011) Enhanced vascularization by controlled release of platelet-rich plasma impregnated in biodegradable gelatin hydrogel. The Annals of thoracic surgery 92:837-844 discussion 844.

53. Roy S, Driggs J, Elgharably H, Biswas S, Findley M, et al. (2011) Plateletrich fibrin matrix improves wound angiogenesis via inducing endothelial cell proliferation. Wound repair and regeneration : official publication of the Wound Healing Society [and] the European Tissue Repair Society 19:753-766.

54. Lundborg G, Dahlin LB, Danielsen NP, Hansson HA, Larsson K (1981) Reorganization and orientation of regenerating nerve fibres, perineurium, and epineurium in preformed mesothelial tubes - an experimental study on the sciatic nerve of rats. J Neurosci Res 6: 265-281.

55. Lundborg G, Dahlin LB, Danielsen N, Hansson HA, Johannesson A, et al. (1982b) Nerve regeneration across an extended gap: a neurobiological view of nerve repair and the possible involvement of neuronotrophic factors. J Hand Surg Am 7: 580-587.

56. Williams LR, Powell HC, Lundborg G, Varon S (1984) Competence of nerve tissue as distal insert promoting nerve regeneration in a silicone chamber. Brain Res 293: 201-211.

57. Williams LR, Varon S (1985) Modification of fibrin matrix formation in situ enhances nerve regeneration in silicone chambers. J Comp Neurol 231: 209-

58. Williams LR (1987) Exogenous fibrin matrix precursors stimulate the temporal progress of nerve regeneration within a silicone chamber. Neurochem Res 12: $851-860$.

59. Williams LR, Danielsen N, Muller $\mathrm{H}$, Varon $\mathrm{S}$ (1987) Exogenous matrix precursors promote functional nerve regeneration across a 15-mm gap within a silicone chamber in the rat. J Comp Neurol 264:284-290.

60. Mackinnon SE, Dellon AL (1988) A comparison of nerve regeneration across a sural nerve graft and a vascularized pseudosheath. J Hand Surg Am 13 935-942.

61. Mackinnon SE, Dellon AL (1990) Clinical nerve reconstruction with a bioabsorbable polyglycolic acid tube. Plast Reconstr Surg 85: 419-424.

62. Mackinnon SE, Dellon AL (1992) Reinnervation of distal sensory nerve environments by regenerating sensory axons. Neuroscience 46: 595-603.

63. Goodhill GJ1 (1997) Diffusion in axon guidance. Eur J Neurosci 9: 1414-1421.

64. Xie FK, Latalladi G, Kuffler DP (1998) Neurotrophic influence of sciatic nervereleased factors on isolated adult motoneurons in vitro. J Peripher Nerv Syst 3: $37-46$.

65. Zheng JQ, Wan JJ, Poo MM (1996) Essential role of filopodia in chemotropic turning of nerve growth cone induced by a glutamate gradient. J Neurosci 16 1140-1149.

66. de la Torre JR, Höpker VH, Ming GL, Poo MM, Tessier-Lavigne M, et al. (1997) Turning of retinal growth cones in a netrin-1 gradient mediated by the netrin receptor DCC. Neuron 19: 1211-1224.

67. Xiang Y, Li Y, Zhang Z, Cui K, Wang S, et al. (2002) Nerve growth cone guidance mediated by $\mathrm{G}$ protein-coupled receptors. Nat Neurosci 5: 843-848. 
Citation: Kuffler DP (2015) Promoting Axon Regeneration and Neurological Recovery Following Traumatic Peripheral Nerve Injuries. Int $\mathrm{J}$ Neurorehabilitation 2: 148. doi:10.4172/2376-0281.1000148

68. Mai J, Fok L, Gao H, Zhang X, Poo MM (2009) Axon initiation and growth cone turning on bound protein gradients. J Neurosci 29: 7450-7458.

69. Beaumont E, Cloutier FC, Atlan M, Rouleau DM, Beaumont PH (2009) Chondroitinase $A B C$ and acute electrical stimulation are beneficial for muscle reinnervation after sciatic nerve transection in rats. Restor Neurol Neurosci 27: 297-305.

70. Snow DM, Letourneau PC (1992) Neurite outgrowth on a step gradient of chondroitin sulfate proteoglycan (CS-PG). J Neurobiol 23: 322-336.

71. Deiner MS, Kennedy TE, Fazeli A, Serafini T, Tessier-Lavigne M, et al. (1997) Netrin-1 and DCC mediate axon guidance locally at the optic disc: loss of function leads to optic nerve hypoplasia. Neuron 19: 575-589.

72. Ming GL, Song HJ, Berninger B, Holt CE, Tessier-Lavigne M, et al. (1997) CAMP-dependent growth cone guidance by netrin-1. Neuron 19: 1225-1235.

73. Grimpe B, Silver J (2002) The extracellular matrix in axon regeneration. Prog Brain Res 137: 333-349.

74. Baier H, Bonhoeffer F (1992) Axon guidance by gradients of a target-derived component. Science 255: 472-475.

75. Kuffler DP (1994b) Promoting and directing axon outgrowth. Mol Neurobiol 9 : 233-243.

76. Kuffler DP (1996) Chemoattraction of sensory neuron growth cones by diffusible concentration gradients of acetylcholine. Mol Chem Neuropathol 28: 199-208.

77. Pérez NL, Sosa MA, Kuffler DP (1997b) Growth cones turn up concentration gradients of diffusible peripheral target-derived factors. Exp Neurol 145: 196202.

78. Kuffler DP (1986b) Isolated satellite cells of a peripheral nerve direct the growth of regenerating frog axons. J Comp Neurol 249: 57-64.

79. Jin M, Guan CB, Jiang YA, Chen G, Zhao CT, et al. (2005) Ca2+-dependent regulation of rho GTPases triggers turning of nerve growth cones. J Neurosci 25: $2338-2347$.

80. Tang S, Zhu J, Xu Y, Xiang AP, Jiang MH, et al. (2013) The effects of gradients of nerve growth factor immobilized PCLA scaffolds on neurite outgrowth in vitro and peripheral nerve regeneration in rats. Biomaterials 34: 7086-7096.

81. Berger A, Millesi H (1978) Nerve grafting. Clin Orthop Relat Res : 49-55

82. Millesi H (1982) Peripheral nerve injuries. Nerve sutures and nerve grafting Scand J Plast Reconstr Surg Suppl 19: 25-37.

83. Jenq CB, Coggeshall RE (1986) The effects of an autologous transplant on patterns of regeneration in rat sciatic nerve. Brain Res 364: 45-56

84. Zalewski AA, Silvers WK, Gulati AK (1982) Failure of host axons to regenerate through a once successful but later rejected long nerve allograft. J Comp Neurol 209: 347-351

85. Ide C, Tohyama K, Yokota R, Nitatori T, Onodera S (1983) Schwann cell basal lamina and nerve regeneration. Brain Res 288: 61-75.

86. Fish JS, Bain JR, McKee N, Mackinnon SE (1992) The peripheral nerve allograft in the primate immunosuppressed with Cyclosporin A: II. Functional evaluation of reinnervated muscle. Plast Reconstr Surg 90: 1047-1052.

87. Cartmell SM, Mitchell D (1994) Diazepam attenuates hyperexcitability and mechanical hypersensitivity of dorsal horn convergent neurones during reperfusion of the rat's tail following ischaemia. Brain Res 659: 82-90.

88. Yamamoto T (1996) [N-methyl-D-aspartate (NMDA) receptor and pain]. Masu 45: 1312-1318.

89. Gordon SM, Dionne RA, Brahim J, Jabir F, Dubner R (1997) Blockade of peripheral neuronal barrage reduces postoperative pain. Pain 70: 209-215

90. Aszmann OC, Korak KJ, Luegmair M, Frey M (2008a) Bridging critical nerve defects through an acellular homograft seeded with autologous schwann cells obtained from a regeneration neuroma of the proximal stump. J Reconstr Microsurg 24:151-158.

91. Nichols CM, Brenner MJ, Fox IK, Tung TH, Hunter DA, et al. (2004) Effects of motor versus sensory nerve grafts on peripheral nerve regeneration. Exp Neurol 190: 347-355.

92. Singh R, Mechelse K, Hop WC, Braakman R (1992) Long-term results of transplantations to repair median, ulnar, and radial nerve lesions by a microsurgical interfascicular autogenous cable graft technique. Surg Neurol 37: $425-431$.
93. Matejcík V (2002) [Reconstructive surgery of the peripheral nerves in the upper extremities with autografts]. Acta Chir Orthop Traumatol Cech 69: 85-87.

94. Belkas JS, Munro CA, Shoichet MS, Midha R (2005b) Peripheral nerve regeneration through a synthetic hydrogel nerve tube. Restor Neurol Neurosci 23: $19-29$

95. Höke A, Redett R, Hameed H, Jari R, Zhou C, et al. (2006b) Schwann cells express motor and sensory phenotypes that regulate axon regeneration. $J$ Neurosci 26: 9646-9655.

96. Karabeg R, Jakirlic M, Dujso V (2009) Sensory recovery after forearm median and ulnar nerve grafting. Med Arh 63: 97-99.

97. Liu Q, Bhat M, Bowen WD, Cheng J (2009) Signaling pathways from cannabinoid receptor-1 activation to inhibition of N-methyl-D-aspartic acid mediated calcium influx and neurotoxicity in dorsal root ganglion neurons. J Pharmacol Exp Ther 331: 1062-1070.

98. Matsumoto K, Ohnishi K, Kiyotani T, Sekine T, Ueda H, et al. (2000) Periphera nerve regeneration across an $80-\mathrm{mm}$ gap bridged by a polyglycolic acid (PGA)collagen tube filled with laminin-coated collagen fibers: a histological and electrophysiological evaluation of regenerated nerves. Brain Res 868: 315-328.

99. Kandenwein JA, Kretschmer T, Engelhardt M, Richter HP, Antoniadis G (2005) Surgical interventions for traumatic lesions of the brachial plexus: a retrospective study of 134 cases. J Neurosurg 103: 614-621.

100. Aszmann OC, Korak KJ, Luegmair M, Frey M (2008b) Bridging critical nerve defects through an acellular homograft seeded with autologous schwann cells obtained from a regeneration neuroma of the proximal stump. Journal of Reconstructive Microsurgery 24:151-158.

101. Terzis JK, Kokkalis ZT (2008) Outcomes of secondary reconstruction of ulnar nerve lesions: our experience. Plast Reconstr Surg 122: 1100-1110.

102. Nichterwitz S, Hoffmann N, Hajosch R, Oberhoffner S, Schlosshauer (2010a) Bioengineered glial strands for nerve regeneration. Neurosci Lett 484 118-122.

103. Fu SY, Gordon T (1995) Contributing factors to poor functional recovery after delayed nerve repair: prolonged denervation. J Neurosci 15: 3886-3895.

104. Gulati AK (1996) Peripheral nerve regeneration through short- and long-term degenerated nerve transplants. Brain Res 742: 265-270.

105. Tung TH, Mackinnon SE (2010) Nerve transfers: indications, techniques, and outcomes. J Hand Surg Am 35: 332-341.

106. Brenner MJ, Hess JR, Myckatyn TM, Hayashi A, Hunter DA, et al. (2006) Repair of motor nerve gaps with sensory nerve inhibits regeneration in rats. Laryngoscope 116: 1685-1692.

107.Jones RH (2010) Repair of the trigeminal nerve: a review. Aust Dent J 55 112-119.

108. Verdú E, Navarro X (1995) [Degeneration and regeneration of the peripheral nervous system with aging]. Rev Neurol 23: 648-655.

109. Verdú E, Ceballos D, Vilches JJ, Navarro X (2000) Influence of aging on peripheral nerve function and regeneration. J Peripher Nerv Syst 5: 191-208.

110. Prang P, Del Turco D, Kapfhammer JP (2001) Regeneration of entorhinal fibers in mouse slice cultures is age dependent and can be stimulated by NT4 , GDNF, and modulators of G-proteins and protein kinase C. Exp Neurol 169: 135-147.

111. Kovacic U, Sketelj J, BajroviÄ FF (2009) Chapter 26: Age-related differences in the reinnervation after peripheral nerve injury. Int Rev Neurobiol 87: 465482.

112. Apel PJ, Ma J, Callahan M, Northam CN, Alton TB, et al. (2010) Effect of locally delivered IGF-1 on nerve regeneration during aging: an experimental study in rats. Muscle Nerve 41: 335-341.

113. Kawabuchi M, Tan H, Wang S (2011) Age affects reciprocal cellular interactions in neuromuscular synapses following peripheral nerve injury. Ageing Res Rev 10: 43-53.

114. Vaughan DW (1992) Effects of advancing age on peripheral nerve regeneration. J Comp Neurol 323: 219-237.

115. Lundborg G, Longo FM, Varon S (1982d) Nerve regeneration model and trophic factors in vivo. Brain Res 232: 157-161.

116. Belkas JS, Munro CA, Shoichet MS, Johnston M, Midha R (2005a) Long-term 
Citation: Kuffler DP (2015) Promoting Axon Regeneration and Neurological Recovery Following Traumatic Peripheral Nerve Injuries. Int $\mathrm{J}$ Neurorehabilitation 2: 148. doi:10.4172/2376-0281.1000148

Page 12 of 17

in vivo biomechanical properties and biocompatibility of poly(2-hydroxyethy methacrylate-co-methyl methacrylate) nerve conduits. Biomaterials 26: 1741 1749 .

117. Kakinoki R, Nishijima N, Ueba Y, Oka M, Yamamuro T, Nakamura T (1997) Nerve regeneration over a $25 \mathrm{~mm}$ gap in rat sciatic nerves using tubes containing blood vessels: the possibility of clinical application. Int Orthop 21:332-336.

118. di Summa PG, Kalbermatten DF, Pralong E, Raffoul W, Kingham PJ, et al. (2011) Long-term in vivo regeneration of peripheral nerves through bioengineered nerve grafts. Neuroscience 181: 278-291.

119. Pettersson J, McGrath A, Kalbermatten DF, Novikova LN, Wiberg M, et al. (2011) Muscle recovery after repair of short and long peripheral nerve gaps using fibrin conduits. Neurosci Lett 500: 41-46.

120. Pereira Lopes FR, Martin PK, Frattini F, Biancalana A, Almeida FM, et al. (2013) Double gene therapy with granulocyte colony-stimulating factor and vascular endothelial growth factor acts synergistically to improve nerve regeneration and functional outcome after sciatic nerve injury in mice. Neuroscience 230 184-197.

121. Reid AJ, de Luca AC, Faroni A, Downes S, Sun M, et al. (2013) Long term peripheral nerve regeneration using a novel PCL nerve conduit. Neurosci Lett 544: 125-130.

122. Brushart TM (1988) Preferential reinnervation of motor nerves by regenerating motor axons. J Neurosci 8: 1026-1031.

123. Griffiths R, Horch K, Stensaas $L$ (1990) A collagen and fibrin tube for nerve repair. Restor Neurol Neurosci 1: 339-346.

124. Gibby WA, Koerber HR, Horch KW (1983) A quantitative evaluation of suture and tubulization nerve repair techniques. J Neurosurg 58: 574-579.

125. Ehashi T, Nishigaito A, Fujisato T, Moritan Y, Yamaoka T (2011) Periphera nerve regeneration and electrophysiological recovery with CIP-treated allogeneic acellular nerves. J Biomater Sci Polym Ed 22: 627-640.

126. Kim BS, Yoo JJ, Atala A (2004) Peripheral nerve regeneration using acellular nerve grafts. J Biomed Mater Res A 68: 201-209.

127. Connolly SS, Yoo JJ, Abouheba M, Soker S, McDougal WS, et al. (2008) Cavernous nerve regeneration using acellular nerve grafts. World J Urol 26 333-339.

128. Whitlock EL, Tuffaha SH, Luciano JP, Yan Y, Hunter DA, et al. (2009a) Processed allografts and type I collagen conduits for repair of peripheral nerve gaps. Muscle Nerve 39: 787-799.

129. Yao L, de Ruiter GC, Wang H, Knight AM, Spinner RJ, et al. (2010) Controlling dispersion of axonal regeneration using a multichannel collagen nerve conduit. Biomaterials 31: 5789-5797.

130. Archibald SJ, Krarup C, Shefner J, Li ST, Madison RD (1991) A collagen-based nerve guide conduit for peripheral nerve repair: an electrophysiological study of nerve regeneration in rodents and nonhuman primates. J Comp Neurol 306 685-696.

131. Alluin O, Wittmann C, Marqueste T, Chabas JF, Garcia S, et al. (2009) Functional recovery after peripheral nerve injury and implantation of a collagen guide. Biomaterials 30: 363-373.

132. Kalbermatten DF, Pettersson J, Kingham PJ, Pierer G, Wiberg M, et al. (2009) New fibrin conduit for peripheral nerve repair. J Reconstr Microsurg 25: 27-33.

133. Nakayama K, Takakuda K, Koyama Y, Itoh S, Wang W, et al. (2007) Enhancement of peripheral nerve regeneration using bioabsorbable polymer tubes packed with fibrin gel. Artif Organs 31: 500-508.

134. Feinberg-Zadek PL, Treistman SN (2007) Beta-subunits are importan modulators of the acute response to alcohol in human BK channels. Alcohol Clin Exp Res 31: 737-744

135. Aguayo AJ, David S, Bray GM (1981) Influences of the glial environment on the elongation of axons after injury: transplantation studies in adult rodents. $J$ Exp Biol 95: 231-240.

136. Anderson PN, Turmaine M (1986b) Peripheral nerve regeneration through grafts of living and freeze-dried CNS tissue. Neuropathol Appl Neurobiol 12 389-399.

137. Kim DH, Connolly SE, Kline DG, Voorhies RM, Smith A, et al. (1994) Labeled Schwann cell transplants versus sural nerve grafts in nerve repair. J Neurosurg 80: 254-260.
138. Xu XM, Guénard V, Kleitman N, Bunge MB (1995) Axonal regeneration into Schwann cell-seeded guidance channels grafted into transected adult rat spinal cord. J Comp Neurol 351: 145-160.

139. Haastert K, Lipokatic E, Fischer M, Timmer M, Grothe C (2006) Differentially promoted peripheral nerve regeneration by grafted Schwann cells overexpressing different FGF-2 isoforms. Neurobiol Dis 21: 138-153.

140.Stang F, Fansa H, Wolf G, Keilhoff G (2005) Collagen nerve conduitsassessment of biocompatibility and axonal regeneration. Biomed Mater Eng 15: 3-12.

141. Kostopoulos E, Konofaos P, Frazer M, Terzis JK (2010) Tubulization techniques in brachial plexus surgery in an animal model for long-nerve defects $(40 \mathrm{~mm})$ : a pilot study. Ann Plast Surg 64: 614-621.

142. Wiesenfeld-Hallin Z, Duranti R (1987) D-ArG, D-Trp7,9, LeU1-substance P (spantide) does not antagonize substance P-induced hyperexcitability of the nociceptive flexion withdrawal reflex in the rat. Acta Physiol Scand 129:55-59.

143. Midha R, Munro CA, Dalton PD, Tator CH, Shoichet MS (2003) Growth factor enhancement of peripheral nerve regeneration through a novel synthetic hydrogel tube. J Neurosurg 99: 555-565.

144. Mohanna PN, Young RC, Wiberg M, Terenghi G (2003) A composite polyhydroxybutyrate-glial growth factor conduit for long nerve gap repairs. J Anat 203: 553-565

145. Lohmeyer JA, Shen ZL, Walter GF, Berger A (2007b) Bridging extended nerve defects with an artifcial nerve graft containing Schwann cells pre-seeded on polyglactin filaments. The International journal of artificial organs 30:64-74.

146. Chang CJ (2009) Effects of nerve growth factor from genipin-crosslinked gelatin in polycaprolactone conduit on peripheral nerve regeneration--in vitro and in vivo. J Biomed Mater Res A 91: 586-596.

147. Ichihara S, Inada Y, Nakada A, Endo K, Azuma T, et al. (2009a) Development of new nerve guide tube for repair of long nerve defects. Tissue Eng Part C Methods 15: 387-402

148. Whitlock EL, Tuffaha SH, Luciano JP, Yan Y, Hunter DA, et al. (2009b) Processed allografts and type I collagen conduits for repair of peripheral nerve gaps. Muscle Nerve 39: 787-799.

149. Hohmann S, Schweinfurth N, Lau T, Deuschle M, Lederbogen F, et al. (2011) Differential expression of neuronal dopamine and serotonin transporters DAT and SERT in megakaryocytes and platelets generated from human MEG-01 megakaryoblasts. Cell Tissue Res 346: 151-161.

150. Aliredjo RP, de Vries J, Menovsky T, Grotenhuis JA, Merx J (1999) The use of Gore-Tex membrane for adhesion prevention in tethered spinal cord surgery: technical case reports. Neurosurgery 44: 674-677.

151. Miloro M, Halkias LE, Mallery S, Travers S, Rashid RG (2002) Low-level lase effect on neural regeneration in Gore-Tex tubes. Oral Surg Oral Med Oral Pathol Oral Radiol Endod 93: 27-34.

152. Inada Y, Morimoto S, Takakura Y, Nakamura T (2004) Regeneration of peripheral nerve gaps with a polyglycolic acid-collagen tube. Neurosurgery 55: 640-646.

153. Anderson PN, Turmaine M (1986a) Axonal regeneration through arterial grafts. J Anat 147: 73-82.

154. Campana WM, Myers RR, Rearden A (2003) Identification of PINCH in Schwann cells and DRG neurons: shuttling and signaling after nerve injury. Glia 41: 213-223

155. Geuna S, Tos P, Battiston B, Giacobini-Robecchi MG (2004) Bridging peripheral nerve defects with muscle-vein combined guides. Neurol Res 26 : 139-144.

156. Itoh S, Shinomiya K, Samejima H, Ohta T, Ishizuki M, et al. (1996) Experimenta study on nerve regeneration through the basement membrane tubes of the nerve, muscle, and artery. Microsurgery 17: 525-534.

157.Collarini EJ, Kuhn R, Marshall CJ, Monuki ES, Lemke G, et al. (1992) Down-regulation of the POU transcription factor SCIP is an early event in oligodendrocyte differentiation in vitro. Development 116: 193-200.

158. Karlsson C, Afrakhte M, Westermark B, Paulsson Y (1999) Elevated level of gas3 gene expression is correlated with $\mathrm{G} 0$ growth arrest in human fibroblasts. Cell Biol Int 23: 351-358.

159. Sasaki R, Aoki S, Yamato M, Uchiyama H, Wada K, et al. (2011) PLGA artificia 
Citation: Kuffler DP (2015) Promoting Axon Regeneration and Neurological Recovery Following Traumatic Peripheral Nerve Injuries. Int $\mathrm{J}$ Neurorehabilitation 2: 148. doi:10.4172/2376-0281.1000148

Page 13 of 17

nerve conduits with dental pulp cells promote facial nerve regeneration. $J$ Tissue Eng Regen Med 5: 823-830.

160. Lohmeyer JA, Shen ZL, Walter GF, Berger A (2007a) Bridging extended nerve defects with an artifcial nerve graft containing Schwann cells pre-seeded on polyglactin filaments. Int J Artif Organs 30: 64-74.

161. Udina E, Ceballos D, Gold BG, Navarro X (2003) FK506 enhances reinnervation by regeneration and by collateral sprouting of peripheral nerve fibers. Exp Neurol 183: 220-231.

162. Tannemaat MR, Boer GJ, Verhaagen J, Malessy MJ (2007) Genetic modification of human sural nerve segments by a lentiviral vector encoding nerve growth factor. Neurosurgery 61:1286-1294; discussion 1294-1286.

163. May F, Matiasek K, Vroemen M, Caspers C, Mrva T, et al. (2008) GDNFtransduced Schwann cell grafts enhance regeneration of erectile nerves. Eur Urol 54: 1179-1187.

164. Ichihara S, Inada Y, Nakada A, Endo K, Azuma T, et al. (2009b) Development of new nerve guide tube for repair of long nerve defects. Tissue Eng Part $C$ Methods 15: 387-402.

165. Nichterwitz S, Hoffmann N, Hajosch R, Oberhoffner S, Schlosshauer B (2010b) Bioengineered glial strands for nerve regeneration. Neurosci Lett 484 118-122.

166. Streppel M, Azzolin N, Dohm S, Guntinas-Lichius O, Haas C, et al. (2002) Focal application of neutralizing antibodies to soluble neurotrophic factors reduces collateral axonal branching after peripheral nerve lesion. Eur J Neurosci 15: 1327-1342.

167. Mears S, Schachner M, Brushart TM (2003) Antibodies to myelin-associated glycoprotein accelerate preferential motor reinnervation. J Peripher Nerv Syst 8: 91-99.

168. Bain JR, Mackinnon SE, Hudson AR, Wade J, Evans P, et al. (1992) The peripheral nerve allograft in the primate immunosuppressed with Cyclosporin A: I. Histologic and electrophysiologic assessment. Plast Reconstr Surg 90: 1036-1046.

169.Zhao Q, Lundborg G, Danielsen N, Bjursten LM, Dahlin LB (1997) Nerve regeneration in a 'pseudo-nerve' graft created in a silicone tube. Brain Res 769: $125-134$

170. Hashimoto T, Suzuki Y, Kitada M, Kataoka K, Wu S, et al. (2002) Peripheral nerve regeneration through alginate gel: analysis of early outgrowth and late increase in diameter of regenerating axons. Exp Brain Res 146: 356-368.

171. Henry EW, Chiu TH, Nyilas E, Brushart TM, Dikkes P, et al. (1985) Nerve regeneration through biodegradable polyester tubes. Exp Neurol 90: 652-676.

172. Farrag TY, Lehar M, Verhaegen P, Carson KA, Byrne PJ (2007) Effect of platelet rich plasma and fibrin sealant on facial nerve regeneration in a rat model. Laryngoscope 117: 157-165.

173. Reyes O, Sosa IJ, Santiago J, Kuffler DP (2007) A novel technique leading to complete sensory and motor recovery across a long peripheral nerve gap. $P$ R Health Sci J 26: 225-228.

174. Piskin A, Kaplan S, Aktas A, Ayyildiz M, Raimondo S, Alic T, Bozkurt HH Geuna $S$ (2009) Platelet gel does not improve peripheral nerve regeneration: an electrophysiological, stereological, and electron microscopic study. Microsurgery 29:144-153.

175. Chiu DT, Janecka I, Krizek TJ, Wolff M, Lovelace RE (1982) Autogenous vein graft as a conduit for nerve regeneration. Surgery $91: 226-233$

176. Johnson EO, Soucacos PN (2008) Nerve repair: experimental and clinical evaluation of biodegradable artificial nerve guides. Injury 39 Suppl 3: S30-36.

177. Li ST, Archibald SJ, Krarup C, Madison RD (1992) Peripheral nerve repair with collagen conduits. Clin Mater 9: 195-200.

178. Terris DJ, Cheng ET, Utley DS, Tarn DM, Ho PR, et al. (1999) Functional recovery following nerve injury and repair by silicon tubulization: comparison of laminin-fibronectin, dialyzed plasma, collagen gel, and phosphate buffered solution. Auris Nasus Larynx 26: 117-122.

179. Wu S, Suzuki Y, Tanihara M, Ohnishi K, Endo K, et al. (2002) Repair of facial nerve with alginate sponge without suturing: an experimental study in cats. Scand J Plast Reconstr Surg Hand Surg 36: 135-140.

180. Chalfoun C, Scholz T, Cole MD, Steward E, Vanderkam V, et al. (2003) Primary nerve grafting: A study of revascularization. Microsurgery 23: 60-65.
181. Murray JA, Willins M, Mountain RE (1993) The use of the rat facial nerve model to assess the effect of differing nerve anastomotic agents on the facial nerve. Clin Otolaryngol Allied Sci 18: 492-495

182. Bartels RH, Menovsky T, Van Overbeeke JJ, Verhagen WI (1998) Surgical management of ulnar nerve compression at the elbow: an analysis of the literature. J Neurosurg 89: 722-727.

183. Midha R, Munro CA, Chan S, Nitising A, Xu QG, et al. (2005) Regeneration into protected and chronically denervated peripheral nerve stumps. Neurosurgery 57: 1289-1299.

184. Tsuchihara T, Nemoto $\mathrm{K}$, Arino H, Amako M, Murakami H, et al. (2008) Sural nerve grafting for long defects of the femoral nerve after resection of a retroperitoneal tumour. J Bone Joint Surg Br 90: 1097-1100.

185. Daly WT, Yao L, Abu-rub MT, O'Connell C, Zeugolis DI, et al. (2012) The effect of intraluminal contact mediated guidance signals on axonal mismatch during peripheral nerve repair. Biomaterials 33: 6660-6671.

186. Lundborg G, Dahlin LB, Danielsen N, Gelberman RH, Longo FM, et al. (1982a) Nerve regeneration in silicone chambers: influence of gap length and of distal stump components. Exp Neurol 76: 361-375.

187. Lundborg G, Gelberman RH, Longo FM, Powell HC, Varon S (1982c) In vivo regeneration of cut nerves encased in silicone tubes: growth across a sixmillimeter gap. J Neuropathol Exp Neurol 41: 412-422.

188. Fields RD, Le Beau JM, Longo FM, Ellisman MH (1989) Nerve regeneration through artificial tubular implants. Prog Neurobiol 33: 87-134.

189. Thomas PK (1966) The cellular response to nerve injury. 1. The cellular outgrowth from the distal stump of transected nerve. J Anat 100: 287-303.

190. Aebischer P, Valentini RF, Winn SR, Galletti PM (1988) The use of a semipermeable tube as a guidance channel for a transected rabbit optic nerve. Prog Brain Res 78: 599-603.

191. Dubový P, Svízenská I (1992) Migration of Schwann cells from the distal stump of the sciatic nerve 1 week after transection: the effects of insulin and cytosine arabinoside. Glia 6: 281-288.

192. Dubový P, Svízenská I (1994) Denervated skeletal muscle stimulates migration of Schwann cells from the distal stump of transected peripheral nerve: an in vivo study. Glia 12: 99-107.

193. Dubový P, Bednárová J (1996) An immunocytochemical analysis of growing axons in a silicone chamber prefilled with artificial sponge matrix. Acta Histochem 98: 123-130.

194. Longo FM, Manthorpe M, Skaper SD, Lundborg G, Varon S (1983) Neuronotrophic activities accumulate in vivo within silicone nerve regeneration chambers. Brain Res 261: 109-116.

195. Longo FM, Hayman EG, Davis GE, Ruoslahti E, Engvall E, et al. (1984) Neurite-promoting factors and extracellular matrix components accumulating in vivo within nerve regeneration chambers. Brain Res 309: 105-117.

196. Politis MJ, Ederle K, Spencer PS (1982) Tropism in nerve regeneration in vivo. Attraction of regenerating axons by diffusible factors derived from cells in distal nerve stumps of transected peripheral nerves. Brain Res 253: 1-12.

197. Le Beau JM, Ellisman MH, Powell HC (1988a) Ultrastructural and morphometric analysis of long-term peripheral nerve regeneration through silicone tubes. $J$ Neurocytol 17: 161-172.

198. Le Beau JM, LaCorbiere M, Powell HC, Ellisman MH, Schubert D (1988b) Extracellular fluid conditioned during peripheral nerve regeneration stimulates Schwann cell adhesion, migration and proliferation. Brain Res 459:93-104.

199. Scaravilli $F$ (1984) The influence of distal environment on peripheral nerve regeneration across a gap. J Neurocytol 13: 1027-1041.

200.Guénard V, Kleitman N, Morrissey TK, Bunge RP, Aebischer P (1992) Syngeneic Schwann cells derived from adult nerves seeded in semipermeable guidance channels enhance peripheral nerve regeneration. J Neurosci 12 : 3310-3320.

201.Zhao Y, Li L, Dai J (1999) Schwann cells and fibronectin treating lesioned spinal cord of adult rats. Chin J Traumatol 2: 110-114.

202. Dubový P, Aldskogius $H$ (1996) Degeneration and regeneration of cutaneous sensory nerve formations. Microsc Res Tech 34: 362-375.

203. Madison R, da Silva CF, Dikkes P, Chiu TH, Sidman RL (1985) Increased rate of peripheral nerve regeneration using bioresorbable nerve guides and $a$ laminin-containing gel. Exp Neurol 88: 767-772. 
Citation: Kuffler DP (2015) Promoting Axon Regeneration and Neurological Recovery Following Traumatic Peripheral Nerve Injuries. Int $\mathrm{J}$ Neurorehabilitation 2: 148. doi:10.4172/2376-0281.1000148

Page 14 of 17

204. Verdú E, Labrador RO, Rodríguez FJ, Ceballos D, Forés J, et al. (2002) Alignment of collagen and laminin-containing gels improve nerve regeneration within silicone tubes. Restor Neurol Neurosci 20: 169-179.

205. Anderson HJ (1982) Do stepping stones guide axon growth? Nature 297: 455456.

206. Maeda T, Mackinnon SE, Best TJ, Evans PJ, Hunter DA, et al. (1993) Regeneration across 'stepping-stone' nerve grafts. Brain Res 618: 196-202.

207. Xu XM, Chen A, Guénard V, Kleitman N, Bunge MB (1997) Bridging Schwann cell transplants promote axonal regeneration from both the rostral and caudal stumps of transected adult rat spinal cord. J Neurocytol 26: 1-16.

208. Brushart TM (1987) Neurotropism and neurotrophism. J Hand Surg Am 12: 808-809.

209. Danielsen N, Kerns JM, Holmquist B, Zhao Q, Lundborg G, et al. (1994) Predegenerated nerve grafts enhance regeneration by shortening the initial delay period. Brain Res 666: 250-254.

210.Danielsen N, Kerns JM, Holmquist B, Zhao Q, Lundborg G, et al. (1995) Predegeneration enhances regeneration into acellular nerve grafts. Brain Res 681: 105-108.

211. Ekström AR, Kanje M, Skottner A (1989) Nerve regeneration and serum levels of insulin-like growth factor-I in rats with streptozotocin-induced insulin deficiency. Brain Res 496: 141-147.

212. Nachemson AK, Lundborg G, Hansson HA (1990) Insulin-like growth factor I promotes nerve regeneration: an experimental study on rat sciatic nerve. Growth Factors 3: 309-314.

213. Hansson HA, Dahlin LB, Danielsen N, Fryklund L, Nachemson AK, et al. (1986) Evidence indicating trophic importance of IGF-I in regenerating peripheral nerves. Acta Physiol Scand 126: 609-614.

214.Sjöberg J, Kanje M, Edström A (1988) Influence of non-neuronal cells on regeneration of the rat sciatic nerve. Brain Res 453: 221-226.

215. Kanje M, Skottner A, Sjöberg J, Lundborg G (1989) Insulin-like growth factor I (IGF-I) stimulates regeneration of the rat sciatic nerve. Brain Res 486: 396 398.

216. Reynolds ML, Woolf CJ (1993) Reciprocal Schwann cell-axon interactions. Curr Opin Neurobiol 3: 683-693.

217. Ridley AJ, Davis JB, Stroobant P, Land H (1989) Transforming growth factorsbeta 1 and beta 2 are mitogens for rat Schwann cells. J Cell Biol 109: 34193424.

218. Scherer SS, Kamholz J, Jakowlew SB (1993) Axons modulate the expression of transforming growth factor-betas in Schwann cells. Glia 8: 265-276.

219. Chen X, Levkowitz G, Tzahar E, Karunagaran D, Lavi S, et al. (1996) An immunological approach reveals biological differences between the two NDF/ heregulin receptors, ErbB-3 and ErbB-4. J Biol Chem 271: 7620-7629.

220. Marchionni MA, Kirk CJ, Isaacs IJ, Hoban CJ, Mahanthappa NK, et al. (1996) Neuregulins as potential drugs for neurological disorders. Cold Spring Harb Symp Quant Biol 61: 459-472.

221.Salzer JL, Williams AK, Glaser L, Bunge RP (1980) Studies of Schwann cell proliferation. II. Characterization of the stimulation and specificity of the response to a neurite membrane fraction. J Cell Biol 84: 753-766.

222. Ratner N, Bunge RP, Glaser L (1985) A neuronal cell surface heparan sulfate proteoglycan is required for dorsal root ganglion neuron stimulation of Schwann cell proliferation. J Cell Biol 101: 744-754.

223. Ratner N, Hong DM, Lieberman MA, Bunge RP, Glaser L (1988) The neuronal cell-surface molecule mitogenic for Schwann cells is a heparin-binding protein. Proc Natl Acad Sci U S A 85: 6992-6996.

224. Morrissey TK, Bunge RP, Kleitman N (1995a) Human Schwann cells in vitro. I. Failure to differentiate and support neuronal health under co-culture conditions that promote full function of rodent cells. J Neurobiol 28: 171-189.

225. Morrissey TK, Kleitman N, Bunge RP (1995b) Human Schwann cells in vitro II. Myelination of sensory axons following extensive purification and heregulininduced expansion. J Neurobiol 28: 190-201.

226. Rich KM, Alexander TD, Pryor JC, Hollowell JP (1989) Nerve growth factor enhances regeneration through silicone chambers. Exp Neurol 105: 162-170.

227. Hollowell JP, Villadiego A, Rich KM (1990) Sciatic nerve regeneration across gaps within silicone chambers: long-term effects of NGF and consideration of axonal branching. Exp Neurol 110: 45-51.

228. Bailey SB, Eichler ME, Villadiego A, Rich KM (1993) The influence of fibronectin and laminin during Schwann cell migration and peripheral nerve regeneration through silicon chambers. J Neurocytol 22: 176-184.

229. Müller HW, Gebicke-Härter PJ, Hangen DH, Shooter EM (1985) A specific 37,000-dalton protein that accumulates in regenerating but not in nonregenerating mammalian nerves. Science 228: 499-501.

230. Hall AK, Rao MS (1992) Cytokines and neurokines: related ligands and related receptors. Trends Neurosci 15: 35-37.

231. Matsuoka I, Nakane A, Kurihara K (1997) Induction of LIF-mRNA by TGF-beta 1 in Schwann cells. Brain Res 776: 170-180.

232. Unsicker K, Grothe C, Westermann R, Wewetzer K (1992) Cytokines in neural regeneration. Curr Opin Neurobiol 2: 671-678.

233. Yamamori T (1991) Localization of cholinergic differentiation factor/leukemia inhibitory factor mRNA in the rat brain and peripheral tissues. Proc Natl Acad Sci U S A 88: 7298-7302.

234. Kim DH, Kam AC, Chandika P, Tiel RL, Kline DG (2001) Surgical management and outcome in patients with radial nerve lesions. J Neurosurg 95: 573-583.

235. Kerns JM, Danielsen N, Holmquist B, Kanje M, Lundborg G (1993) The influence of predegeneration on regeneration through peripheral nerve grafts in the rat. Exp Neurol 122: 28-36.

236. Sorenson EJ, Windebank AJ (1993) Relative importance of basement membrane and soluble growth factors in delayed and immediate regeneration of rat sciatic nerve. J Neuropathol Exp Neurol 52: 216-222.

237. Salonen V, Aho H, Röyttä M, Peltonen J (1988) Quantitation of Schwann cells and endoneurial fibroblast-like cells after experimental nerve trauma. Acta Neuropathol 75: 331-336.

238. Heumann R (1987) Regulation of the synthesis of nerve growth factor. J Exp Biol 132: 133-150

239. Röyttä M, Salonen V (1988) Long-term endoneurial changes after nerve transection. Acta Neuropathol 76: 35-45.

240. Hill ES, Latalladi G, Kuffler DP (1999) Dissociated adult Rana pipiens motoneuron growth cones turn up concentration gradients of denervated peripheral nerve-released factors. Neurosci Lett 277: 87-90.

241. Tohyama K, Ide C, Osawa T (1990) Nerve regeneration through the cryoinjured allogeneic nerve graft in the rabbit. Acta Neuropathol 80: 138-144.

242. Siironen J, Vuorinen V, Taskinen HS, Röyttä M (1995) Axonal regeneration into chronically denervated distal stump. 2. Active expression of type I collagen mRNA in epineurium. Acta Neuropathol 89: 219-226.

243. Brandt J, Nilsson A, Kanje M, Lundborg G, Dahlin LB (2005) Acutelydissociated Schwann cells used in tendon autografts for bridging nerve defects in rats: a new principle for tissue engineering in nerve reconstruction. Scand J Plast Reconstr Surg Hand Surg 39: 321-325.

244. Madison RD, Robinson GA (2014) Accuracy of regenerating motor neurons: influence of diffusion in denervated nerve. Neuroscience 273: 128-140.

245. Nilsson A, Dahlin L, Lundborg G, Kanje M (2005) Graft repair of a peripheral nerve without the sacrifice of a healthy donor nerve by the use of acutely dissociated autologous Schwann cells. Scand J Plast Reconstr Surg Hand Surg 39: 1-6.

246. Dahlin L, Brandt J, Nilsson A, Lundborg G, Kanje M (2007) Schwann cells, acutely dissociated from a predegenerated nerve trunk, can be applied into a matrix used to bridge nerve defects in rats. Acta Neurochir Suppl 100: 57-59.

247. Braunewell KH, Martini R, LeBaron R, Kresse H, Faissner A, et al. (1995) Up-regulation of a chondroitin sulphate epitope during regeneration of mouse sciatic nerve: evidence that the immunoreactive molecules are related to the chondroitin sulphate proteoglycans decorin and versican. Eur J Neurosci 7 : 792-804.

248. Zuo J, Hernandez YJ, Muir D (1998b) Chondroitin sulfate proteoglycan with neurite-inhibiting activity is up-regulated following peripheral nerve injury. $\mathrm{J}$ Neurobiol 34:41-54.

249. Groves ML, McKeon R, Werner E, Nagarsheth M, Meador W, et al. (2005) Axon regeneration in peripheral nerves is enhanced by proteoglycan degradation. Exp Neurol 195: 278-292. 
Citation: Kuffler DP (2015) Promoting Axon Regeneration and Neurological Recovery Following Traumatic Peripheral Nerve Injuries. Int $\mathrm{J}$ Neurorehabilitation 2: 148. doi:10.4172/2376-0281.1000148

Page 15 of 17

250. Schwartz NB (1977) Regulation of chondroitin sulfate synthesis. Effect of betaxylosides on synthesis of chondroitin sulfate proteoglycan, chondroitin sulfate chains, and core protein. J Biol Chem 252: 6316-6321.

251. Margolis RK, Goossen B, Tekotte H, Hilgenberg L, Margolis RU (1991) Effects of beta-xylosides on proteoglycan biosynthesis and morphology of PC2 pheochromocytoma cells and primary cultures of rat cerebellum. J Cell Sci $99: 237-246$

252. Yick LW, Wu W, So KF, Yip HK, Shum DK (2000) Chondroitinase ABC promotes axonal regeneration of Clarke's neurons after spinal cord injury. Neuroreport 11: 1063-1067.

253. Cheng H, Cao Y, Olson L (1996) Spinal cord repair in adult paraplegic rats: partial restoration of hind limb function. Science 273: 510-513.

254.Samardzic MM, Rasulic LG, Grujicic DM (1997) Gunshot injuries to the brachial plexus. J Trauma 43: 645-649.

255. de Vries J, Menovsky T, Grotenhuis JA, van Overbeeke JJ (1998) Protective coating of cranial nerves with fibrin glue (Tissucol) during cranial base surgery: technical note. Neurosurgery 43: 1242-1246.

256. Iwaya K, Mizoi K, Tessler A, Itoh Y (1999) Neurotrophic agents in fibrin glue mediate adult dorsal root regeneration into spinal cord. Neurosurgery 44: 589 595.

257. Menovsky T, van Overbeeke JJ (1999) On the mechanism of transient postoperative deficit of cranial nerves. Surg Neurol 51: 223-226.

258. Becker CM, Gueuning CO, Graff GL (1984) Sutures of fibrin glue for divided rat nerves. Schwann cell and muscle metabolism. J Reconstr Microsurg 1: 139-145.

259. Herter T, Anagnostopoulos-Schleep J, Bennefeld H (1989) [The effect of fibrin gluing and its important components on fibrosis of nerve anastomoses]. Unfallchirurgie 15: 221-229.

260.Zhou S (1990) [Anastomosis of peripheral nerves by fibrin glue. An experimental study]. Zhonghua Wai Ke Za Zhi 28: 689-692, 704.

261. Povlsen B, Hildebrand C, Wiesenfeld-Hallin Z, Stankovic N (1993) Functiona projection of regenerated rat sural nerve axons to the hindpaw skin after sciatic nerve lesions. Exp Neurol 119: 99-106.

262. Murray JA, Willins M, Mountain RE (1994b) A comparison of glue and a tube as an anastomotic agent to repair the divided buccal branch of the rat facial nerve. Clin Otolaryngol Allied Sci 19: 190-192.

263. Maquet V, Martin D, Malgrange B, Franzen R, Schoenen J, et al. (2000) Peripheral nerve regeneration using bioresorbable macroporous polylactide scaffolds. J Biomed Mater Res 52: 639-651.

264. Cruz NI, Debs N, Fiol RE (1986) Evaluation of fibrin glue in rat sciatic nerve repairs. Plast Reconstr Surg 78: 369-373.

265. Jin Y, Dehesdin D, Hemet J, Bagot D'arc C, Creissard P, et al. (1990) [Comparative experimental study of nerve repairs by classical suture or biological adhesive]. Neurochirurgie 36: 378-382.

266. Murray JA, Mountain R, Willins M (1994a) Best method for facial nerve anastomosis. Eur Arch Otorhinolaryngol .

267.Povlsen B (1994) A new fibrin seal in primary repair of peripheral nerves. $J$ Hand Surg $[\mathrm{Br}]$ 19:43-47.

268. Drew SJ, Fullarton AC, Glasby MA, Mountain RE, Murray JA (1995) Reinnervation of facial nerve territory using a composite hypoglossal nerve-muscle autograft--facial nerve bridge. An experimental model in sheep. Clin Otolaryngol Allied Sci 20: 109-117.

269. Becker C, Gueuning C, Graff G (1985) [Peripheral nerve repair: value of biological glues and epiperineural suture in late interventions. Experimental study in rats]. Ann Chir Main 4: 259-262.

270. Rodríguez FJ, Verdú E, Ceballos D, Navarro X (2000) Nerve guides seeded with autologous schwann cells improve nerve regeneration. Exp Neurol 161: 571-584.

271. Navarro X, Rodríguez FJ, Ceballos D, Verdú E (2003) Engineering an artificial nerve graft for the repair of severe nerve injuries. Med Biol Eng Comput 41: 220-226.

272. Lopatina T, Kalinina N, Karagyaur M, Stambolsky D, Rubina K, et al. (2011) Adipose-derived stem cells stimulate regeneration of peripheral nerves: BDNF secreted by these cells promotes nerve healing and axon growth de novo. PLoS One 6: E7899.
273. Mahay D, Terenghi G, Shawcross SG (2008) Growth factors in mesenchyma stem cells following glial-cell differentiation. Biotechnol Appl Biochem 51: 167176.

274. Huang W, Begum R, Barber T, Ibba V, Tee NC, et al. (2012) Regenerative potential of silk conduits in repair of peripheral nerve injury in adult rats. Biomaterials 33: 59-71.

275. Allmeling C, Jokuszies A, Reimers K, Kall S, Choi CY, et al. (2008) Spider silk fibres in artificial nerve constructs promote peripheral nerve regeneration. Cell Prolif 41: 408-420.

276. Cai J, Peng X, Nelson KD, Eberhart R, Smith GM (2004) Synergistic improvements in cell and axonal migration across sciatic nerve lesion gaps using bioresorbable filaments and heregulin-betA. J Biomed Mater Res A 69 247-258.

277. Timmer M, Robben S, Müller-Ostermeyer F, Nikkhah G, Grothe C (2003) Axonal regeneration across long gaps in silicone chambers filled with Schwann cells overexpressing high molecular weight FGF-2. Cell Transplant 12: $265-277$.

278. Strauch B, Rodriguez DM, Diaz J, Yu HL, Kaplan G, et al. (2001) Autologous Schwann cells drive regeneration through a $6-\mathrm{cm}$ autogenous venous nerve conduit. J Reconstr Microsurg 17: 589-595.

279. Saheb-Al-Zamani M, Yan Y, Farber SJ, Hunter DA, Newton P, et al. (2013) Limited regeneration in long acellular nerve allografts is associated with increased Schwann cell senescence. Exp Neurol 247: 165-177.

280. Sun XH, Che YQ, Tong XJ, Zhang LX, Feng Y, et al. (2009) Improving nerve regeneration of acellular nerve allografts seeded with SCs bridging the sciatic nerve defects of rat. Cell Mol Neurobiol 29: 347-353.

281. Yang Y, Yuan X, Ding F, Yao D, Gu Y, et al. (2011a) Repair of rat sciatic nerve gap by a silk fibroin-based scaffold added with bone marrow mesenchymal stem cells. Tissue Eng Part A 17: 2231-2244.

282. Shen H, Shen ZL, Zhang PH, Chen NL, Wang YC, et al. (2010) Ciliary neurotrophic factor-coated polylactic-polyglycolic acid chitosan nerve conduit promotes peripheral nerve regeneration in canine tibial nerve defect repair. $J$ Biomed Mater Res B Appl Biomater 95: 161-170.

283. Xue C, Hu N, Gu Y, Yang Y, Liu Y, et al. (2012) Joint use of a chitosan PLGA scaffold and MSCs to bridge an extra large gap in dog sciatic nerve. Neurorehabil Neural Repair 26: 96-106.

284. Wang X, Luo E, Li Y, Hu J (2011) Schwann-like mesenchymal stem cells within vein graft facilitate facial nerve regeneration and remyelination. Brain Res 1383: 71-80.

285. Liard O, Segura S, Sagui E, Nau A, Pascual A, Cambon M, Darlix JL, Fusa T, Moyse $E$ (2012) Adult-brain-derived neural stem cells grafting into a vein bridge increases postlesional recovery and regeneration in a peripheral nerve of adult pig. Stem Cells Int 2012:128732.

286. Wang D, Liu XL, Zhu JK, Hu J, Jiang L, Zhang Y, Yang LM, Wang HG, Zhu QT, Yi JH, Xi TF (2010) Repairing large radial nerve defects by acellular nerve allografts seeded with autologous bone marrow stromal cells in a monkey model. J Neurotrauma 27:1935-1943.

287. Moore AM, MacEwan M, Santosa KB, Chenard KE, Ray WZ, et al. (2011) Acellular nerve allografts in peripheral nerve regeneration: a comparative study. Muscle Nerve 44: 221-234.

288. Fang Y, Mo X, Guo W, Zhang M, Zhang P, et al. (2010) A new type of Schwann cell graft transplantation to promote optic nerve regeneration in adult rats. $J$ Tissue Eng Regen Med 4: 581-589.

289. Koppes AN, Seggio AM, Thompson DM (2011) Neurite outgrowth is significantly increased by the simultaneous presentation of Schwann cells and moderate exogenous electric fields. J Neural Eng 8: 046023.

290. Gordon T, Brushart TM, Chan KM (2008) Augmenting nerve regeneration with electrical stimulation. Neurol Res 30: 1012-1022.

291. Gordon T, Udina E, Verge VM, de Chaves El (2009b) Brief electrical stimulation accelerates axon regeneration in the peripheral nervous system and promotes sensory axon regeneration in the central nervous system. Motor Control 13:412-441.

292. Gordon T, Chan KM, Sulaiman OA, Udina E, Amirjani N, et al. (2009a) Accelerating axon growth to overcome limitations in functional recovery after peripheral nerve injury. Neurosurgery 65: A32-144. 
Citation: Kuffler DP (2015) Promoting Axon Regeneration and Neurological Recovery Following Traumatic Peripheral Nerve Injuries. Int $\mathrm{J}$ Neurorehabilitation 2: 148. doi:10.4172/2376-0281.1000148

Page 16 of 17

293.Behan BL, DeWitt DG, Bogdanowicz DR, Koppes AN, Bale SS, et al. (2011) Single-walled carbon nanotubes alter Schwann cell behavior differentially within 2D and 3D environments. J Biomed Mater Res A 96: 46-57.

294. Yao CH, Chang RL, Chang SL, Tsai CC, Tsai FJ, et al. (2012) Electrical stimulation improves peripheral nerve regeneration in streptozotocin-induced diabetic rats. J Trauma Acute Care Surg 72: 199-205.

295. Belenky M, Devor M (1997) Association of postganglionic sympathetic neurons with primary afferents in sympathetic-sensory co-cultures. J Neurocytol 26: 715-731.

296. Gordon T (2009) The role of neurotrophic factors in nerve regeneration. Neurosurg Focus 26: E3.

297.Li YT, Peng CW, Chen LT, Lin WS, Chu CH, et al. (2013) Application of implantable wireless biomicrosystem for monitoring nerve impedance of rat after sciatic nerve injury. IEEE Trans Neural Syst Rehabil Eng 21: 121-128.

298. Lin YC, Kao CH, Cheng YK, Chen JJ, Yao CH, et al. (2014b) Current-modulated electrical stimulation as a treatment for peripheral nerve regeneration in diabetic rats. Restor Neurol Neurosci 32: 437-446.

299. Al-Majed AA, Brushart TM, Gordon T (2000a) Electrical stimulation accelerates and increases expression of BDNF and trkB mRNA in regenerating rat femoral motoneurons. Eur J Neurosci 12: 4381-4390.

300. Hinderer SR, Dixon K (2001) Physiologic and clinical monitoring of spastic hypertonia. Phys Med Rehabil Clin N Am 12: 733-746.

301. Geremia NM, Gordon T, Brushart TM, Al-Majed AA, Verge VM (2007) Electrical stimulation promotes sensory neuron regeneration and growth-associated gene expression. Exp Neurol 205: 347-359.

302. Gordon T, Brushart TM, Amirjani N, Chan KM (2007) The potential of electrical stimulation to promote functional recovery after peripheral nerve injurycomparisons between rats and humans. Acta Neurochir Suppl 100: 3-11.

303. Udina E, Furey M, Busch S, Silver J, Gordon T, et al. (2008) Electrica stimulation of intact peripheral sensory axons in rats promotes outgrowth of their central projections. Exp Neurol 210: 238-247.

304. Brushart TM, Hoffman PN, Royall RM, Murinson BB, Witzel C, et al. (2002) Electrical stimulation promotes motoneuron regeneration without increasing its speed or conditioning the neuron. J Neurosci 22: 6631-6638.

305. Ahlborn P, Schachner M, Irintchev A (2007) One hour electrical stimulation accelerates functional recovery after femoral nerve repair. Exp Neurol 208: 137-144.

306. Singh B, Xu QG, Franz CK, Zhang R, Dalton C, et al. (2012) Accelerated axon outgrowth, guidance, and target reinnervation across nerve transection gaps following a brief electrical stimulation paradigm. J Neurosurg 116: 498-512.

307. Gordon T, Sulaiman O, Boyd JG (2003) Experimental strategies to promote functional recovery after peripheral nerve injuries. J Peripher Nerv Syst 8: 236250.

308. Al-Majed AA, Tam SL, Gordon T (2004) Electrical stimulation accelerates and enhances expression of regeneration-associated genes in regenerating rat femoral motoneurons. Cell Mol Neurobiol 24: 379-402.

309. Runge MB, Dadsetan M, Baltrusaitis J, Ruesink T, Lu L, et al. (2010) Development of electrically Conductive Oligo(polyethylene glycol) fumaratepolypyrrole hydrogels for nerve regeneration. Biomacromolecules 11: 28452853.

310. Liu G, Cheng Y, Guo S, Feng Y, Li Q, et al. (2011) Transplantation of adiposederived stem cells for peripheral nerve repair. Int J Mol Med 28: 565-572.

311. Zhang Y, Luo H, Zhang Z, Lu Y, Huang X, et al. (2010) A nerve graft constructed with xenogeneic acellular nerve matrix and autologous adipose-derived mesenchymal stem cells. Biomaterials 31: 5312-5324.

312. Wang Y, Zhao Z, Ren Z, Zhao B, Zhang L, et al. (2012) Recellularized nerve allografts with differentiated mesenchymal stem cells promote peripheral nerve regeneration. Neurosci Lett 514: 96-101.

313. Mimura T, Dezawa M, Kanno H, Sawada H, Yamamoto I (2004) Peripheral nerve regeneration by transplantation of bone marrow stromal cell-derived Schwann cells in adult rats. J Neurosurg 101: 806-812.

314. Hsu SH, Kuo WC, Chen YT, Yen CT, Chen YF, et al. (2013) New nerve regeneration strategy combining laminin-coated chitosan conduits and stem cell therapy. Acta Biomater 9: 6606-6615.
315. Lu X, Richardson PM (1995) Changes in neuronal mRNAs induced by a local inflammatory reaction. J Neurosci Res 41: 8-14.

316. Batchelor PE, Wills TE, Hewa AP, Porritt MJ, Howells DW (2008) Stimulation of axonal sprouting by trophic factors immobilized within the wound core. Brain Res 1209: 49-56.

317. Kwon MJ, Kim J, Shin H, Jeong SR, Kang YM, et al. (2013) Contribution of macrophages to enhanced regenerative capacity of dorsal root ganglia sensory neurons by conditioning injury. J Neurosci 33: 15095-15108.

318. Lee SC, Tsai CC, Yao CH, Hsu YM, Chen YS, et al. (2013) Effect of arecoline on regeneration of injured peripheral nerves. Am J Chin Med 41: 865-885.

319. Mokarram N, Merchant A, Mukhatyar V, Patel G, Bellamkonda RV (2012) Effect of modulating macrophage phenotype on peripheral nerve repair Biomaterials 33: 8793-8801.

320. Johnson PJ, Newton P, Hunter DA, Mackinnon SE (2011) Nerve endoneuria microstructure facilitates uniform distribution of regenerative fibers: a post hoc comparison of midgraft nerve fiber densities. J Reconstr Microsurg 27: 83-90.

321. Donzelli R, Maiuri F, Piscopo GA, de Notaris M, Colella A, et al. (2006) Role of extracellular matrix components in facial nerve regeneration: an experimental study. Neurol Res 28: 794-801.

322. Chen YG, Brushart TM (1998) The effect of denervated muscle and Schwann cells on axon collateral sprouting. J Hand Surg Am 23: 1025-1033.

323. Neal RA, Tholpady SS, Foley PL, Swami N, Ogle RC, et al. (2012) Alignment and composition of laminin-polycaprolactone nanofiber blends enhance peripheral nerve regeneration. J Biomed Mater Res A 100: 406-423.

324. Kuffler DP, Megwinoff O (1994) Neurotrophic influence of denervated sciatic nerve on adult dorsal root ganglion neurons. J Neurobiol 25: 1267-1282.

325. Dobretsov M, Dobretsov A, Kuffler DP (1994) Influence of factors released from sciatic nerve on adult dorsal root ganglion neurons. J Neurobiol 25: 12491266 .

326. Moore K, MacSween M, Shoichet M (2006) Immobilized concentration gradients of neurotrophic factors guide neurite outgrowth of primary neurons in macroporous scaffolds. Tissue Eng 12: 267-278.

327. Yang Y, Zhao W, He J, Zhao Y, Ding F, et al. (2011b) Nerve conduits based on immobilization of nerve growth factor onto modified chitosan by using genipin as a crosslinking agent. Eur J Pharm Biopharm 79: 519-525.

328. Lin Q, Cai Y, Li H (2014a) Experimental study on gradient of nerve growth factor immobilized conduits promoting peripheral nerve regeneration in rats. Zhongguo Xiu Fu Chong Jian Wai Ke Za Zhi 28: 167-172.

329. Berrocal YA, Almeida VW, Gupta R, Levi AD (2013) Transplantation of Schwann cells in a collagen tube for the repair of large, segmental peripheral nerve defects in rats. J Neurosurg 119: 720-732.

330. Arthur A, Shi S, Zannettino AC, Fujii N, Gronthos S, et al. (2009) Implanted adult human dental pulp stem cells induce endogenous axon guidance. Stem Cells 27: 2229-2237.

331.Lee EJ, Xu L, Kim GH, Kang SK, Lee SW, et al. (2012) Regeneration of peripheral nerves by transplanted sphere of human mesenchymal stem cells derived from embryonic stem cells. Biomaterials 33: 7039-7046.

332. Gold BG (1997) FK506 and the role of immunophilins in nerve regeneration. Mol Neurobiol 15: 285-306.

333. Steiner JP, Connolly MA, Valentine HL, Hamilton GS, Dawson TM, et al. (1997) Neurotrophic actions of nonimmunosuppressive analogues of immunosuppressive drugs FK506, rapamycin and cyclosporin A. Nat Med 3: 421-428.

334. Webster HD (1997) Growth factors and myelin regeneration in multiple sclerosis. Mult Scler 3: 113-120.

335. Doolabh VB, Mackinnon SE (1999) FK506 accelerates functional recovery following nerve grafting in a rat model. Plast Reconstr Surg 103: 1928-1936.

336. Fansa H, Keilhoff G, Horn T, Altmann S, Wolf G, et al. (1999) [Stimulation of Schwann cell growth and axon regeneration of peripheral nerves by the immunosuppressive drug FK 506]. Handchir Mikrochir Plast Chir 31: 323-329.

337. Amoureux MC, Cunningham BA, Edelman GM, Crossin KL (2000) N-CAM binding inhibits the proliferation of hippocampal progenitor cells and promotes their differentiation to a neuronal phenotype. J Neurosci 20: 3631-3640. 
Citation: Kuffler DP (2015) Promoting Axon Regeneration and Neurological Recovery Following Traumatic Peripheral Nerve Injuries. Int $\mathrm{J}$ Neurorehabilitation 2: 148. doi:10.4172/2376-0281.1000148

338. Chunasuwankul R, Ayrout C, Dereli Z, Gal A, Lanzetta M, et al. (2002) Low dose discontinued FK506 treatment enhances peripheral nerve regeneration. Int Surg 87: 274-278.

339. Sulaiman OA, Voda J, Gold BG, Gordon T (2002) FK506 increases peripheral nerve regeneration after chronic axotomy but not after chronic schwann cell denervation. Exp Neurol 175: 127-137.

340. Lanzetta M, Gal A, Wright B, Owen E (2003a) Effect of FK506 and basic fibroblast growth factor on nerve regeneration using a polytetrafluoroethylene chamber for nerve repair. Int Surg 88: 47-51.

341. Steed DL (2006) Clinical evaluation of recombinant human platelet-derived growth factor for the treatment of lower extremity ulcers. Plast Reconstr Surg 117:143S-149S; discussion 150S-151S

342. Konofaos P, Terzis JK (2013) FK506 and nerve regeneration: past, present and future. J Reconstr Microsurg 29: 141-148.

343. Azizi S, Mohammadi R, Amini K, Fallah R (2012) Effects of topically administered FK506 on sciatic nerve regeneration and reinnervation after vein graft repair of short nerve gaps. Neurosurg Focus 32: E5.

344. Lanzetta M, Gal A, Wright B, Owen E (2003b) Effect of FK506 and basic fibroblast growth factor on nerve regeneration using a polytetrafluoroethylene chamber for nerve repair. Int Surg 88: 47-51.

345.Ziegenhorn AA, Schulte-Herbruggen O, Danker-Hopfe $H$, Malbranc $M$, Hartung HD, Anders D, Lang UE, Steinhagen-Thiessen E, Schaub RT, Hellweg R (2007) Serum neurotrophins--a study on the time course and influencing factors in a large old age sample. Neurobiol Aging 28:1436-1445.

346. Chen SH, Chang FM, Chang HK, Chen WC, Huang KF, et al. (2007) Human umbilical cord blood-derived CD34+ cells cause attenuation of multiorgan dysfunction during experimental heatstroke. Shock 27: 663-671.

347. Lyons WE, George EB, Dawson TM, Steiner JP, Snyder SH (1994) Immunosuppressant FK506 promotes neurite outgrowth in cultures of PC2 cells and sensory ganglia. Proc Natl Acad Sci U S A 91: 3191-3195.

348. Lyons WE, Steiner JP, Snyder SH, Dawson TM (1995) Neuronal regeneration enhances the expression of the immunophilin FKBP-12. J Neurosci 15: 29852994.

349. Gold BG, Gordon HS, Wang MS (1999) Efficacy of delayed or discontinuous FK506 administrations on nerve regeneration in the rat sciatic nerve crush model: lack of evidence for a conditioning lesion-like effect. Neurosci Lett 267: 33-36.

350. Ruddell RG, Oakley F, Hussain Z, Yeung I, Bryan-Lluka LJ, et al. (2006) A role for serotonin (5-HT) in hepatic stellate cell function and liver fibrosis. Am J Pathol 169: 861-876.
351. Gordon T, Tyreman N, Raji MA (2011) The basis for diminished functional recovery after delayed peripheral nerve repair. J Neurosci 31: 5325-5334.

352. Rueger MA, Aras S, Guntinas-Lichius O, Neiss WF (2008) Re-activation of atrophic motor Schwann cells after hypoglossal-facial nerve anastomosis. Neurosci Lett 434: 253-259.

353. Sulaiman OA, Gordon T (2009) Role of chronic Schwann cell denervation in poor functional recovery after nerve injuries and experimental strategies to combat it. Neurosurgery 65: A05-114.

354. Birge RB, Wadsworth S, Akakura R, Abeysinghe H, Kanojia R, et al (2004) A role for schwann cells in the neuroregenerative effects of a nonimmunosuppressive fk506 derivative, jnj460. Neuroscience 124: 351-366.

355.Zuo J, Hernandez YJ, Muir D (1998c) Chondroitin sulfate proteoglycan with neurite-inhibiting activity is up-regulated following peripheral nerve injury. $J$ Neurobiol 34:41-54

356. Muir D, Engvall E, Varon S, Manthorpe M (1989) Schwannoma cell-derived inhibitor of the neurite-promoting activity of laminin. J Cell Biol 109: 2353-2362.

357.Zuo J, Ferguson TA, Hernandez YJ, Stetler-Stevenson WG, Muir D (1998a) Neuronal matrix metalloproteinase-2 degrades and inactivates a neuriteinhibiting chondroitin sulfate proteoglycan. J Neurosci 18: 5203-5211.

358. Cheng $\mathrm{H}$, Almström S, Olson L (1995) Fibrin glue used as an adhesive agent in CNS tissues. J Neural Transplant Plast 5: 233-243.

359. Cheng H, Almström S, Giménez-Llort L, Chang R, Ove Ogren S, et al. (1997) Gait analysis of adult paraplegic rats after spinal cord repair. Exp Neurol 148 544-557.

360.Ding XG, Li SW, Zheng XM, Hu LQ, Hu WL, et al. (2008) [Effect of platelet rich plasma on the regeneration of cavernous nerve: experiment with rats] Zhonghua Yi Xue Za Zhi 88: 2578-2580.

361. Kim JY, Jeon WJ, Kim DH, Rhyu IJ, Kim YH, et al. (2014) An inside-out vein graft filled with platelet-rich plasma for repair of a short sciatic nerve defect in rats. Neural Regen Res 9: 1351-1357.

362.Zheng C, Zhu Q, Liu X, Huang X, He C, et al. (2014) Improved peripheral nerve regeneration using acellular nerve allografts loaded with platelet-rich plasma. Tissue Eng Part A 20: 3228-3240.

363. Kuffler DP (2014) An assessment of current techniques for inducing axon regeneration and neurological recovery following peripheral nerve trauma. Prog Neurobiol 116: 1-12.

364. Feneley MR, Fawcett JW, Keynes RJ (1991) The role of Schwann cells in the regeneration of peripheral nerve axons through muscle basal lamina grafts. Exp Neurol 114: 275-285. 